NBER WORKING PAPER SERIES

HUMAN CAPITALISTS

Andrea L. Eisfeldt

Antonio Falato

Mindy Z. Xiaolan

Working Paper 28815

http://www.nber.org/papers/w28815

\author{
NATIONAL BUREAU OF ECONOMIC RESEARCH \\ 1050 Massachusetts Avenue \\ Cambridge, MA 02138 \\ May 2021, Revised April 2022
}

We thank our discussants Lars Alexander-Kuehn, Francois Gourio, Daniel Greenwald, and Thomas Lemieux, as well as Erik Hurst, Matthias Kehrig, Lee Ohanian, Valerie Ramey, and seminar and conference participants at the NBER Summer Institute Micro Data and Macro Models Workshop, the Society of Economic Dynamics Annual Meeting, the MIT Junior Finance Conference, ASU Sonoran Winter Finance Conference, the Macro Finance Society Biannual Meeting, Texas Finance Festival, WUSTL the Macroeconomics of Inequality Mini-Conference, AFA, Boston University, Columbia University, the University of Minnesota, the University of Illinois Urbana-Champaign, the London School of Economics, the University of Texas at Austin, MIT, Stanford, UC Davis, Northwestern University, the University of Chicago, Carnegie Mellon University, Georgetown University, Princeton University, Upenn Wharton School, University of Toronto, London Business School for their helpful comments. Xiaolan gratefully acknowledges the financial support from the faculty excellence research grant from the McCombs School of Business at the University of Texas at Austin. The views expressed herein are those of the authors and do not necessarily reflect the views of the National Bureau of Economic Research.

NBER working papers are circulated for discussion and comment purposes. They have not been peer-reviewed or been subject to the review by the NBER Board of Directors that accompanies official NBER publications.

(C) 2021 by Andrea L. Eisfeldt, Antonio Falato, and Mindy Z. Xiaolan. All rights reserved. Short sections of text, not to exceed two paragraphs, may be quoted without explicit permission provided that full credit, including $\odot$ notice, is given to the source. 


\title{
Human Capitalists
}

Andrea L. Eisfeldt, Antonio Falato, and Mindy Z. Xiaolan

NBER Working Paper No. 28815

May 2021, Revised April 2022

JEL No. E0,E25,G3

\begin{abstract}
$\underline{\text { ABSTRACT }}$
The widespread and growing use of equity-based compensation has transformed high-skilled labor from a pure labor input to a class of "human capitalists." High-skilled labor earns substantial income in the form of equity claims to firms' future dividends and capital gains. Equity-based compensation has increased substantially since the 1980s, representing thirty-six percent of total compensation to high-skilled labor in US manufacturing in recent years. Ignoring equity income causes incorrect measurement of the returns to high-skilled labor, with substantial effects on macroeconomic trends. In manufacturing, the inclusion of equity-based compensation almost eliminates the decline in the high-skilled labor share, and reduces the total decline in the labor share by about one-third. Only by including equity pay does our structural estimation support complementarity between high-skilled labor and physical capital greater than that of Cobb and Douglas (1928). We also provide additional regression evidence of such complementarity.

Andrea L. Eisfeldt

Anderson School of Management

University of California at Los Angeles

110 Westwood Plaza

Suite C4.10

Los Angeles, CA 90095

and NBER

andrea.eisfeldt@anderson.ucla.edu

Antonio Falato

Federal Reserve Board

Mail Stop \#89

20th Street \& Constitution Ave. NW

Washington, DC 20551

antonio.falato@frb.gov

Mindy Z. Xiaolan

University of Texas at Austin

2110 Speedway B6600

Austin, TX 78703

mindy.xiaolan@mccombs.utexas.edu
\end{abstract}

A live draft link is available at https://sites.google.com/site/andrealeisfeldt/ human_capitalists.pdf?attredirects $=0$ 


\section{Introduction}

Human capitalists are corporate employees who receive significant equity-based compensation such as equity grants and stock options. These employees are partial owners of US firms, and in return for their human capital input, human capitalists accrue a share of firm profits through firm dividends and capital gains in addition to earning wages. We document the stylized facts describing the evolution of human capitalists' income over time and across industries within the US manufacturing sector 1 Human capitalists have become an increasingly important class of corporate income earners. Due to measurement challenges, prior work has underestimated the importance of equity pay below the C-suite. Correctly measuring the total income of human capitalists income substantially alters conclusions about changes in factor shares and technological complementarity.

Equity-based compensation represents $36 \%$ of compensation to human capitalists in the most recent decade, and constitutes a 7\% share of value added in the manufacturing sector in 2019 . Correctly accounting for the total income earned by high-skilled workers has a substantial effect on measured changes in labor shares over the modern era. The addition of equity pay to cash wages reduces the decline implied by the wage-only income share of value added in manufacturing since the 1980 s by $32 \%$. Without including equity pay, high-skilled labor's share decreased from $17 \%$ in the 1980 s to $11 \%$ in the most recent decade. The inclusion of equity-based compensation almost eliminates this decline. The high-skilled share of total labor income increases from one third at the beginning of the 1960s to two thirds in the 2010s when equity-based compensation is included.

Firms use equity pay for several reasons. Because it is deferred, it is an effective retention tool. Equity pay may also be used due to favorable tax treatment at the personal level, to incentivize effort, or to boost current earnings (and borrow from employees). Our estimation indicates that, on average, $98 \%$ of equity pay has been used to replace wages as compensation for marginal product rather than to increase pay overall. Equity-based compensation is widely used beyond the muchstudied executive level. In recent years $78 \%$ of equity-based compensation went to employees outside

\footnotetext{
${ }^{1}$ We focus on the manufacturing sector because the Census of Manufacturing data provides a wages-only measure, to which we add our corresponding estimates of annual equity pay from firm-level data. Alvarez-Cuadrado et al. (2018) shows that the decline in the labor share occurred predominantly in the manufacturing sector. See also Kehrig and Vincent (2020), who uses detailed microdata within the manufacturing sector to show that a reallocation of value added to lower labor share units has been a key driver of the decline in the labor share, and Acemoglu and Restrepo (2019), who argues that an important part of the declining labor share is that workers in manufacturing in particular have been displaced by automation.
} 
the C-suite.

Our study contributes important new facts to the study of changing factor shares, and the implications for the distributions of income and wealth. Elsby, Hobijn, and Şahin (2013) and Karabarbounis and Neiman (2014) show that the labor share measured using national accounting data has declined in the US corporate sector since the early 1980s. Wage growth has been anemic relative to the growth of corporate profits. These facts seem to indicate a secular shift of income away from the providers of labor to the owners of physical capital. However, tackling the capital structure question of who owns firms' profits is necessary to provide a concrete link between changing factor shares and changing income and wealth shares. Human capitalists are an important class of firm owners.

Our findings documenting rising equity pay in public manufacturing firms are distinct but complementary to recent work by Smith, Yagan, Zidar, and Zwick (2018) which emphasizes the mismeasurement of labor income as capital income compensation in the private sector. They argue that, in the private sector, firm owners' equity claims are labor compensation as opposed to passive capital income. Smith, Yagan, Zidar, and Zwick (2021) documents the effect of the growing share of pass-through enterprises on the decline in the labor share. Their focus is on the entrepreneurial labor income of small business owners while ours is on the equity income of high-skilled employees at large corporations. The link between investment in intangible assets and missing labor income in the form of sweat equity is emphasized in McGrattan and Prescott (2010), who document a puzzling increase in hours and capital gains in the 1990s when wages measured in national accounts were low $2^{2}$ Further evidence on labor-share mismeasurement is documented in the recent paper Koh, Santaeulàlia-Llopis, and Zheng (2020), which points out the mechanical negative effect on the labor share of the BEA's revision to the capital accounts to include intellectual property products in capital income $3^{3}$

We find that the total labor share has declined since the 1960s even including equity pay in our sample of manufacturing firms. Our sample also displays a relatively flat share of physical capital in value added, consistent with Barkai (2017) and Rognlie (2015). In light of these trends,

\footnotetext{
${ }^{2}$ See also Bhandari and McGrattan $\sqrt{2020)}$ and McGrattan $(2020)$.

${ }^{3}$ See p. 2, "The current accounting assumption is to attribute the entire gross investment in business IPP to gross operating surplus (GOS), i.e., to capital income." See also Atkeson (2020) for a measure of the labor share that is unaffected by the BEA's accounting changes.
} 
Karabarbounis and Neiman (2019) coined the term "factorless income" and documented measurement methods to reduce the share of income that is unaccounted for by observable factors. Farhi and Gourio (2018) and Greenwald, Lettau, and Ludvigson (2019) study the quantitative role of markups, intangible assets, and/or risk premia in driving a growing profit or factorless-income share using the discipline of a larger set of macroeconomic and financial market moments. By appropriately allocating profits earned in exchange for labor inputs to the labor share of human capitalists, equity compensation is an important way to reduce factorless income. In our sample, human capitalists' ownership share of public companies is $10 \%$ in the 2010 s. Thus, their share of profits reduces factorless income by this amount. Human capitalists in the manufacturing sector earned over $\$ 136$ billion annually in equity-based compensation from publicly traded firms on average over the most recent decade. Importantly, not only have firm profits grown, the ownership share of human capitalists grew as well.

We start by carefully documenting the stylized facts describing the secular evolution of human capitalists' income share. The key measurement challenge is to compute the annual flow of equitybased compensation granted to human capitalists each year. There are two main reasons that the majority of equity pay is missing from standard data sources for annual labor compensation such as the Bureau of Economic Analysis (BEA) and the Bureau of Labor Statistics (BLS). First, a substantial fraction of equity pay is qualified by the internal revenue service to be taxed at the long-term capital gains tax rate. Second, equity pay is substantially deferred, on average by five or more years. Thus, newly granted equity pay does not appear in standard data sources based on current income tax or unemployment data, even if it will be taxed as income once it is vested and exercised. Because equity pay has grown at a very high rate since the 1980s, vested and exercised pay are a small fraction of new grants. To see that the majority of equity pay is not included in national accounting compensation data, note that the IRS reports that the value of income from the exercise of nonstatutory stock options (the only equity pay that flows through the IRS form W2 that underlies the BEA and BLS data) averaged only $\$ 55$ Billion per year over the period 20082017 This total covers the entire economy, whereas we estimate equity pay to be $\$ 100$ Billion on average within the manufacturing sector alone during this same time period. We provide further details on the treatment of equity compensation in standard data sources in Section 2.3 below, and

\footnotetext{
${ }^{4}$ See Table 5A of the publicly-available W2 data available at https://www.irs.gov/pub/irs-soi/17inallw2.xls.
} 
describe how to estimate the small fraction of equity-based pay that is included in W2 forms and in BEA compensation data. The Census payroll series we add equity-based compensation to in order to compute total human capitalist income for our main analysis is wages only.

To surpass the challenges in measuring equity pay, we use firm-level data on the value of shares reserved for compensation. By law, firms must reserve shares against compensation grants in order to disclose the expected resulting dilution to shareholders. Data on shares reserved for employees' unexercised stock options or restricted equity grants are available annually for the universe of publicly traded US corporations via their SEC filings. We obtain data on shares reserved for equitybased compensation from 1960-2019 by combining datasets based on SEC filings when available, and hand collecting the SEC data otherwise. Using the assembled data on the stock of reserved shares, along with its law of motion, we construct a measure of the annual flow of new equity-based compensation grants each year. We then aggregate to the industry level and add high-skilled wages from a merged NBER-CES-public-firm sample to obtain a measure of total compensation to highskilled labor. Our merged NBER-CES-pubic-firm data set covers a very broad set of manufacturing firms and contains a reliable measure of value added 5

A rising share of human capitalist income, along with the observed decline in investment goods prices, is consistent with technological complementarity between human and physical capital. We explore this potential complementarity in two ways. First, we provide robust panel-data evidence for complementarity between high-skilled labor and physical capital at both the industry and firm level. Second, we conduct a structural estimation that highlights the importance of equity-based compensation when evaluating evidence of complementarity between human capital and physical capital.

Our panel regressions first document a negative relationship within firms and within industries over time between investment goods prices and high-skilled human capital owners' earnings and wealth. Human capitalists' income has increased more in industries and firms that have experienced larger declines in investment goods prices ${ }^{6}$ Thus, the evidence suggests that human capitalists have benefited disproportionately from declining investment goods prices. Next, we use the correctly

\footnotetext{
${ }^{5}$ We show in the Internet Appendix that the factor shares (excluding equity-based compensation) in our merged sample are nearly identical to those in the broader NBER-CES data set.

${ }^{6}$ See also Kehrig and Vincent (2020) for a detailed analysis of the dynamics of the labor share in the cross section of production units.
} 
measured total return to human capitalists to show that within industries and over time, there is a positive relation between the human capital share and the physical capital share (which is consistent with complementarity). By contrast, and consistent with the cross-country evidence in Karabarbounis and Neiman (2014), we find a negative relation between the low-skilled labor share and capital shares. Our evidence supports substitutability between low-skilled labor and capital.

We develop and study a parsimonious model and then estimate its key parameters (a) to provide structure for the facts that describe the rise of human capitalists and (b) to understand the implications of these facts for shares of value added and income. Our model builds on the model developed in Krusell, Ohanian, Rìs-Rull, and Violante (2000), who were the first to model and document the complementarity between high-skilled labor and physical capital. Notably, their sample ends in 1992. During the internet boom in the mid 1990s the decline in high-skilled wage income and the rise in the equity pay of human capitalists accelerated. Indeed, our estimation indicates that the post 1992 steep decline in the high-skilled wage share implies greater substitutability between high-skilled labor and capital than Cobb and Douglas (1928) when equity pay is not included. However, using the total compensation of high-skilled labor, including equity pay, the elasticity of substitution we estimate in our model is nearly identical to that in Krusell et al. (2000) (0.66 vs. 0.67) 7 Thus, including equity pay is crucial for finding complementarity greater than that of Cobb and Douglas (1928) in recent years in which wage income has been replaced by equity pay at the high end of the income distribution.

In addition to constructing a more comprehensive measure of high-skilled labor compensation, we modify the theoretical framework in Krusell et al. (2000) in two key ways to accommodate human capitalists. First, we treat high-skilled human capital as a stock that can be accumulated through investment rather than as a flow labor input. Second, in our framework, this stock of human capital earns an equilibrium return that can depend not only on its current marginal product but also on its outside option (e.g., Eisfeldt and Papanikolaou (2013), Hartman-Glaser, Lustig, and Xiaolan (2019)). Importantly, we show that only a small fraction of equity-based pay must be assigned to human capitalists' marginal product in order to generate a degree of complementarity between

\footnotetext{
${ }^{7}$ See also the more recent work by Ohanian et al. (2021). That paper revisits the original Krusell et al. (2000) model with updated data and also finds evidence of declining complementarity between high-skilled labor and capital. They find that the elasticity of substitution is closer to one using updated data ( 0.76 in updated data vs. 0.67 in Krusell et al. (2000)). See the updated parameters in Tables 5.2 and 5.3, and the related discussion.
} 
physical and human capital that is larger than the complementarity implied by Cobb-Douglas. Our estimates indicate that $98 \%$ of equity pay is used as a substitute for wages to compensate marginal product, as opposed to being used as additional pay or rents from the participation constraint. Our estimate of the elasticity of substitution between capital and unskilled labor is 1.28 , and is not sensitive to the fraction of equity-based pay assigned to marginal product. This finding on the substitutability between capital and unskilled labor is broadly consistent with the estimates in the existing literature (e.g. Krusell et al. (2000), Karabarbounis and Neiman (2014)). Our model at estimated parameters and with correctly measured income shares is able to replicate the full set of stylized facts we document when the economy receives the observed sequence of declining investment goods prices.

Our paper contributes to the following related areas of the literature. First, there is an ongoing discussion on the secular evolution of factor shares (e.g., Elsby et al. (2013), Karabarbounis and Neiman (2014), Lawrence (2015), Koh et al. (2016), Autor, Dorn, Katz, Patterson, and Reenen (2017), Hartman-Glaser et al. (2019), Kehrig and Vincent (2020)). This literature has established the decline of the aggregate labor share measured using standard sources of realized income (mainly wages). While our data also support a declining overall labor share, we emphasize the importance of using a more complete measure of total compensation in the modern era. Our new compensation series also contributes important new facts that help make to progress on the evolution of total income share dynamics for workers of different skill levels.

Our focus on investment-specific technological change builds on the earlier macroeconomics and asset pricing literature (e.g., Greenwood, Hercowitz, and Krusell (1997), Papanikolaou (2011), Kogan and Papanikolaou (2014), Krusell et al. (2000)). Despite this growing literature, there is still a limited amount of direct cross-sectional evidence on the relation between investment goods prices and factor shares (Acemoglu (2002)). We examine the implications of investment-specific technological change on factor shares, and use new micro data to characterize the shape of an aggregate production function which employs human capitalists. Our study also contributes to our understanding of who gains and who loses from investment-specific technological change 8 Including equity-based compensation greatly increases the observed disparity between the compensation

\footnotetext{
${ }^{8}$ See also the recent study Jaimovich et al. (Forthcoming), who argue that incorporating the quality of goods produced is crucial for measuring the interaction between skill-biased technical change and the skill premium, as well as Caunedo et al. (2019) for a study of differential occupational exposure to capital-embodied technical change.
} 
of high and low skilled labor, deepening concerns regarding the unequal sharing of the gains to technological progress highlighted by Autor (2014) and Autor (2019).

Our analysis has related implications for the broader debate on the income distribution between capital and labor, and the concern regarding rising inequality (e.g., Piketty (2014), Caicedo, Robert E. Lucas, and Rossi-Hansberg (2016), Gabaix, Lasry, Lions, and Moll (2016), Stokey (2016)), which on the finance side has generally focused on the very top of the income distribution (e.g., Gabaix and Landier (2008), Kaplan and Rauh (2010), Frydman and Saks (2010), Frydman and Papanikolaou (2015)). Given the data limitations, very little was previously known about the total compensation to the intermediate levels of the income distribution represented by high-skilled laborers. An important exception is Lemieux, MacLeod, and Parent (2009), which documents increasing performance-based pay in the Panel Study of Income Dynamics and the effects on income inequality, but does not focus on equity-based pay and the implications for factor shares. Our analysis highlights the importance of equity compensation paid to employees below the very top executive or founder level. Whereas total compensation at the C-suite level appears to have peaked around the year 2000, equity-based compensation to a broader set of high-skilled labor continues to rise. See the comprehensive summary of the facts that describe executive compensation in Frydman and Jenter (2010).

Finally, a growing literature in macroeconomics and finance highlights the importance of a "missing factor," and in particular intangible capital embedded in, and partially owned by, human inputs or organization capital (e.g., Eisfeldt and Papanikolaou (2014), Koh et al. (2016), Barkai (2017), Karabarbounis and Neiman (2019), Benzell and Brynjolfsson (2019)). We bring new microdata to the measurement of human inputs. Moreover, we examine the importance of the rents generated by organizational capital from a national income accounting perspective, which, aside from the notable exceptions above, has received limited attention thus far.

\section{Human Capitalist Income: Measurement and Stylized Facts}

In this section, we first provide a detailed description of our method for measuring the total income to human capitalists, including wages and new equity grants using NBER-CES and Compustat data. Using corrected total human capitalist income, we then document the implications of the 
revised labor income series for macro trends in factor shares. Our main findings highlight the large magnitude of human capitalists' equity-based compensation, which has grown markedly over the past four decades. Next, we show how to construct total human capitalist income in BEA data, in which a minority of equity pay is included. First, we describe the reasons why standard sources largely exclude equity-based pay. Then, we provide a way to estimate the amount of equity pay that is included in BEA data and document the effect of equity pay on the labor share decline measured with that data. In manufacturing, we estimate that only $35 \%$ of current equity grants are included in the BEA income measure.

Following our construction of the main stylized facts documenting the growth in equity pay we provide panel-data evidence in support of technological complementarity between physical capital and human capital from high-skilled labor. Specifically, we show a robust negative relation between investment goods prices and human capitalists' income shares, which holds in the time series in the cross-section of industries, as well as within firms over time. We also provide evidence on the relation between investment goods prices and human capitalist wealth.

\subsection{Measuring Total Human Capitalist Income}

Data Sources We describe our main data sources. Additional details appear in the Appendix. The income of human capitalists consists of two parts. The first is traditional compensation to highskilled human capitalists in the form of wages. The second part, which is novel to our analysis, is compensation from restricted equity or stock option grants.

Wages, value added, and investment goods prices are obtained at the four-digit SIC code level from the NBER-CES Manufacturing Industry Database, which is based largely on the Annual Survey of Manufacturing data sets (Becker, Gray, and Marvakov (2013)).9 The NBER-CES is particularly useful for our purposes, as it provides a "clean" measure of wages; these data are payroll only, and explicitly exclude fringe benefits and equity compensation, as we document in the Appendix.10

\footnotetext{
${ }^{9}$ The NBER-CES data set includes 459 (140) unique industries at the 4-SIC (3-SIC) level. Most of the variables in the NBER-CES are taken from the Annual Surveys of Manufacturing, while price deflators and depreciation rates are derived from other data published by the Census Bureau, the Bureau of Economic Analysis, the Bureau of Labor Statistics, and the Federal Reserve Board. NBER-CES data and documentation are available at http://www.nber.org/nberces.

${ }^{10} \mathrm{See}$ also https://www.census.gov/programs-surveys/asm/technical-documentation/questionnaire/ 2019-annual-survey-of-manufactures-forms.html.
} 
To surpass the challenges faced by standard data sources using employer or employee tax data, we construct our baseline measure of equity-based compensation using widely available firm-level data on shares reserved for employee compensation from public-firm SEC filings. We utilize firms' reporting of shares reserved for employee compensation to construct our firm-level annual time series of new equity grants. This data is reported by Compustat for the time period 1960-1995. Compustat data are constructed from 10-K statements filed with the SEC and cover the universe of publicly traded US firms. For the subsequent subsample, from 1996-2005, we utilize data from RiskMetrics. RiskMetrics (formerly the Investor Responsibility Research Center (IRRC)) covers firms from the S\&P 500, S\&P midcap, and S\&P smallcap indexes, and is also sourced from 10$\mathrm{K}$ statements filed with the SEC. The IRRC dataset is aimed at providing compensation and governance information, and thus contains additional useful details on grants and vesting. For the 2006-2019 period, we hand-collected the reserved shares data for the industries covered in the NBER-CES dataset from firms' 10-K filings and/or proxy statements available from SEC Edgar.

The merged public firm/NBER-CES data set covers all firms in the manufacturing and health sectors, as well as roughly half of the firms in the consumer goods and high-tech sectors. The combined data set for the 1960-2019 period is composed of 133 4-digit-SIC code industries and 5,271 firms. The covered sectors represent over $40 \%$ of the aggregate value of sales in the publicfirm universe. We show in the Internet Appendix that factor share dynamics using wage data only in the full NBER-CES universe are nearly identical to those in our merged sample. When constructing our measure of new grants relative to value added, we use industry-level sales from each data source to scale the public firm data to match the public and private establishment data covered by the NBER-CES data set.

Human Capitalist Income: Wages We designate the NBER-CES category of non-production workers as high-skilled laborers, following the standard treatment of this category in labor economics. The validity of utilizing the category of non-production workers to represent high-skilled labor has been previously established in the labor literature by, for example, Berman, Bound, and Griliches (1994), Pierce and Schott (2016), and Acemoglu, Dorn, Hanson, Price, et al. (2014). The time series of high-skilled wages as a share of value added is plotted in Figure 2, Note the pronounced decline in the high-skilled income share using wages only, from $17 \%$ in 1960 to $11 \%$ in 2019. However, compensation using wages only is incomplete. Equity pay is crucial for fully 
measuring the differential effects of technological progress on high and low skilled labor highlighted by Autor (2014) and Autor (2019).

Human Capitalist Income: Equity Pay Our main measurement challenge is to gather comprehensive information on the equity-based component of current income, which comes from equity grants in the form of restricted stock or unvested stock options. We overcome this challenge using firm-level data on shares reserved for employee compensation to generate annual firm-level observations on the contemporaneous flow of equity-based pay. Securities law requires firms to disclose shares reserved for compensation in order to disclose the expected dilution to existing shareholders. To be in compliance with the SEC, firms must reserve shares in an amount that reflects the mispricing, and resulting dilution to existing shareholders, from issuing shares to employees at below market prices. Reserved shares are authorized by the board of directors, and appear as a treasury stock liability on firms' balance sheets. Compustat defines the reserved share $(R S)$ variable as the item that “... represents shares reserved for stock options outstanding as of year-end plus options that are available for future grants.' 11

Reserved shares is a stock variable, whereas we are interested in the annual flow of new equity grants. Intuitively, we can convert the stock of reserved shares into an annual flow by dividing the stock by the average time that a reserved share remains on the balance sheet before it is granted as compensation. Denote this average granting period as $g p$. We provide a formal derivation of our flow measure of equity-based compensation, new grants, or, $N G=R S / g p$, in Appendix 6.2.2 using a law of motion for reserved shares which accounts for authorization, exercise, and expiration. We then use the RiskMetrics data from 1996-2005 to estimate the weighted-average granting period as the ratio of compensation grants to reserved shares. During this period, the weighted-average granting period, $g p$, is 5.69 years ${ }^{12}$ To be conservative, we then use a weighted-average granting period of six years to estimate the annual flow of equity-based compensation grants from the endof-year stock of reserved shares.

Our equity-based compensation data is obtained from publicly-traded firms' accounting statements, while value-added is obtained from the aggregate NBER-CES industry-level database, which includes survey data from manufacturing establishments of both public and private firms. After

\footnotetext{
${ }^{11}$ It is our understanding from accounting rules that the reserved share variable also includes shares reserved for restricted stock grants, but if not, our measure is conservative for that reason.

${ }^{12}$ The median of the granting period across industries is 5.68 years.
} 
dropping public firms in industries not covered by the NBER-CES Manufacturing Database, there are two remaining potential mismatches when aggregating the firm-level value of $N G$ to the industry level: First, the NBER-CES database includes private firms, causing a downward bias to our NG/value-added ratio. Second, publicly-traded firms have foreign establishments, and they may grant equity compensation to employees in foreign establishments while the NBER-CES data covers domestic manufacturing establishments only. Therefore, to adjust the new grant series based on public firms to the NBER-CES industry measures of value added, we scale each industry aggregate $N G$ by the corresponding sales ratio between the public-firm industry aggregate and the NBER-CES industry value (see the Appendix for details).

Note that, because our estimates are derived from firm-level data and not worker-level data, we cannot identify the precise recipients of equity-based compensation. We allocate all of equity pay to high-skilled labor. IRS data shows that $97 \%$ of equity pay goes to earners in the top $10 \%$ of the income distribution for the available sample from 2008-2017, and this fraction is nearly constant over that time period 13 Other auxiliary data sources, such as levels.fyi, suggest that equity-based compensation is used heavily for engineers and for a broad set of managers. We use an expense-based measure below to provide additional evidence that total compensation to white-collar workers has increased from 1980-2019. Finally, using ExecuComp, we show that most equity-based compensation (78\% in recent years) goes to workers below the C-suite.

Figure 1 reports the aggregate $N G$ as a share of aggregate value added in our sample (the solid line). Income from equity-based compensation grows from less than $1 \%$ of value added before 1980 to as much as $7 \%$ in the $2010 \mathrm{~s}$. We also measure the share of total equity that human capitalists own. We define the ownership share of human capitalists as the ratio of the value of shares reserved for employee equity-based compensation (i.e., RS) to the stock market capitalization of the firm 14 This share, also plotted in Figure 1 (the dotted line), captures the fraction of firm value which is employee-owned. Human capitalists have owned $10 \%$ of total public firms' market capitalization on average over the last decade, compared to $3 \%$ in the 1980 s. The rise of the ownership share

\footnotetext{
${ }^{13}$ The cutoff for the 90 th income percentile was $\$ 108,000$ in 2017 . See Table 6 A of the publicly-available W2 data available at https://www.irs.gov/pub/irs-soi/17inallw2.xls. See also McGrattan and Prescott (2010), who emphasize the outsized earnings from capital gains by managerial and professional workers in the Federal Reserve's Survey of Consumer Finances.

${ }^{14}$ Scaling the value of reserved shares by the stock market valuation helps alleviate the potential concern of market timing. Companies may issue more equity-based compensation when stock prices are high.
} 
indicates that the increase in human capitalists' income is not just driven by rising corporate valuations. Human capitalists have benefited disproportionately from increasing corporate profits because their ownership share also increased.

Figure 1: Equity-Based Compensation: Time Series

This plot reports the time series of human capitalists' equity-based compensation in the manufacturing sector, both the annual flow and the stock. The annual flow of total reserved shares for employees' equity-based compensation, $N G$, is calculated as the aggregate value of outstanding reserved shares normalized by the average granting period of 6 years. The solid line is the time series of the $N G$ to value added ratio. The dashed line is the time series of the ownership share, measured by the ratio of the value of reserved shares $(R S)$ for employee equity-based compensation to stock market capitalization.

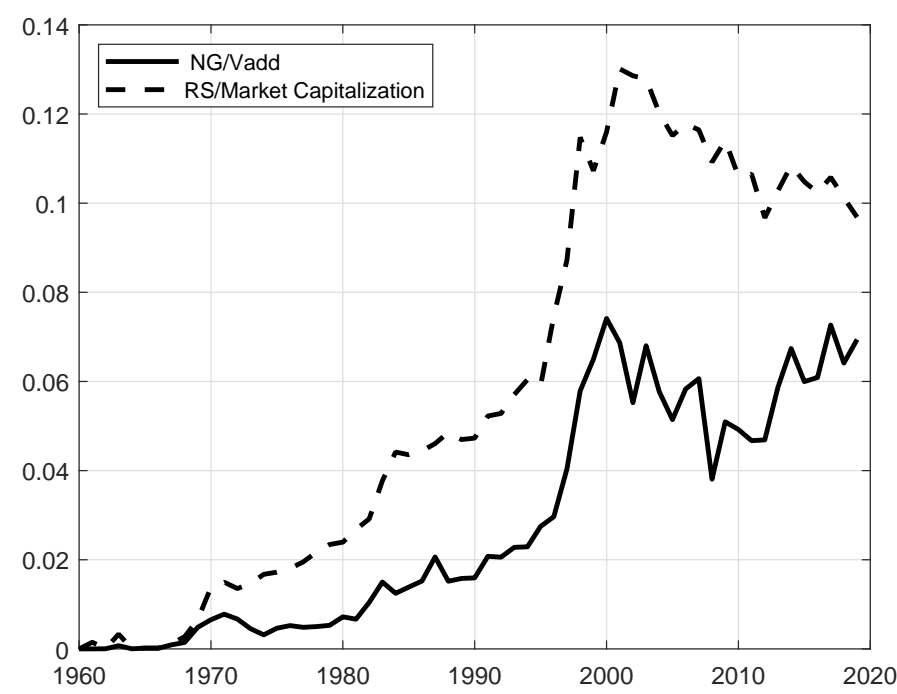

Human Capitalist Income, Total: Wages plus Equity Human capitalists earn both wages and equity compensation. While human capitalists' wage share of value added has been trending down, equity pay has replaced wage compensation in recent decades. To construct human capitalists' total income, we add equity pay to wages to form their total compensation. We plot the time series of the total income share along with the wage share and equity-based compensation share in Figure 2. The figure shows that the increase in equity-based compensation essentially offsets the decline in high-skilled wage income. The human capitalists' total labor share declined by $1 \%$ from 1980 s to 2010 s compared to the $6 \%$ decline in human capitalists wage-only share from 1980 s to 2010s. Including the equity-based pay cuts the decline in the wage-only human capitalists income share by $87 \%$. The fact that the total high-skilled labor share is essentially flat is consistent with our estimate of the fraction of equity pay that is used to compensate marginal product, which is 
Figure 2: Human Capital Share of Income and Total Labor Share

Panel (a) reports human capitalists' total income share and its composition. The dashed blue line is the human capitalists' flow wage income, calculated as the total labor income share minus the production labor income share (from the NBER-CES Manufacturing Industry Database) minus an estimate of the total value of exercised employee stock options. The dashed black line is the ratio of equity-based compensation $(N G)$ to value added. The total human capitalists' income share is the sum of the wage income share and the equity-based income share. Panel (b) reports the total labor share before and after adjusting for equity-based compensation. The dotted blue line is the aggregate wage-only income from NBER-CES. The dashed black line is the ratio of equity-based compensation (NG) to value added. The total labor income share is the sum of the wage income share and the equity-based income share. Data source: Compustat Fundamental Annual (1960-1996), RiskMetrics (IRRC) (1996-2011), and NBER-CES Manufacturing Industry Database (1960-2005). The sample period is from 1960 to 2019.

(a) Human Capitalists' Income Share

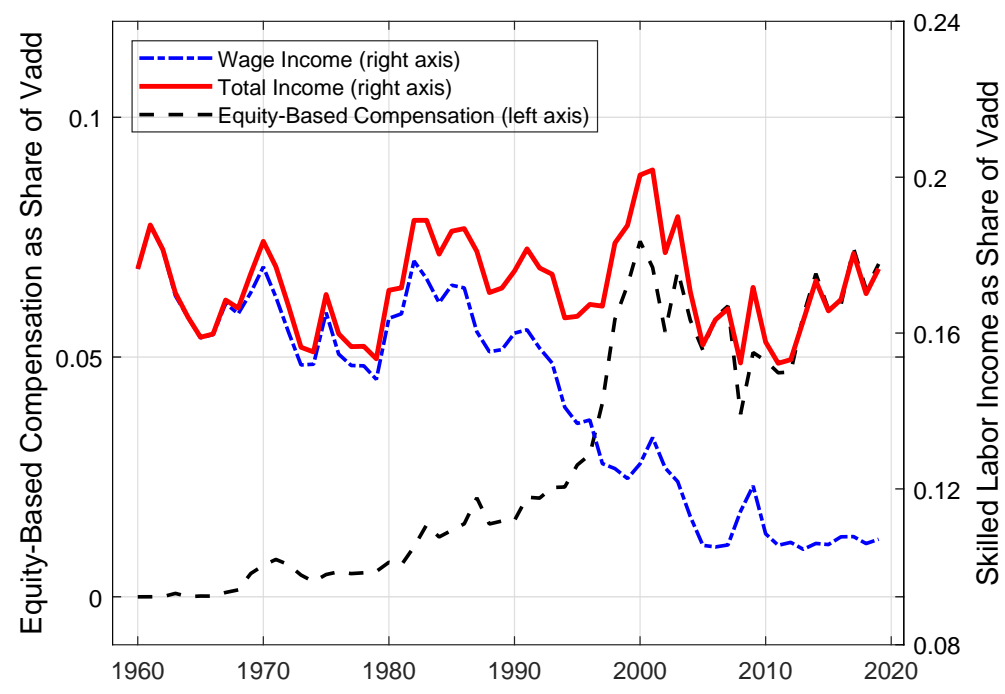

(b) Total Labor Share

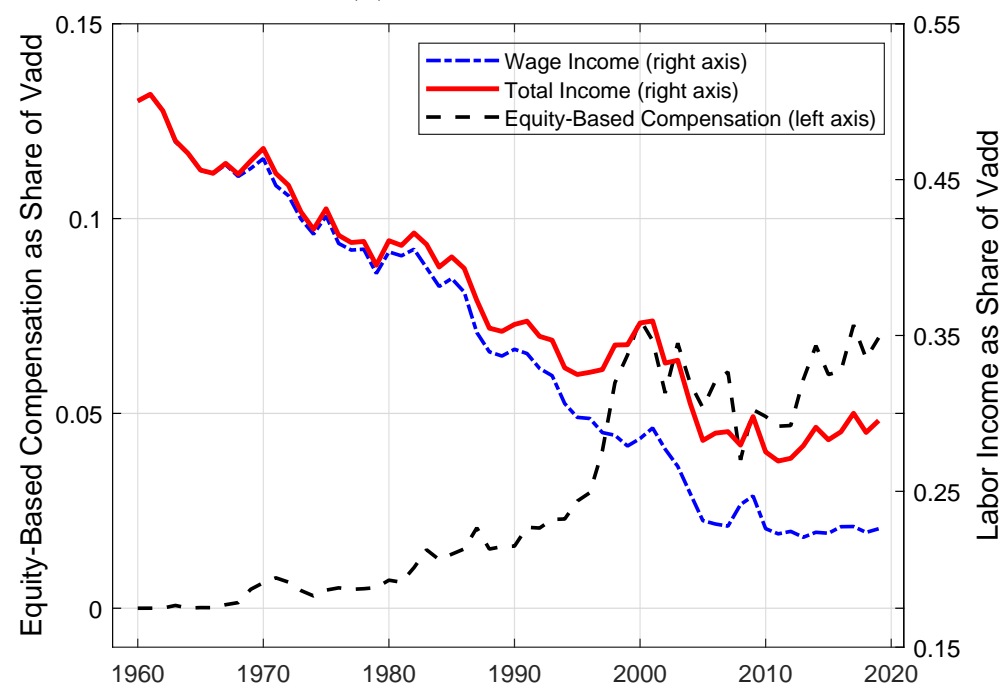


$91 \%$, indicating that, in large part, equity has simply replaced wages, leaving the high-skilled labor share fairly constant.

Human Capitalist Income, Total: Wages plus Equity, Robustness and Discussion As a robustness check, we compare our main approach to measuring total human capitalist compensation as the sum of equity-based compensation from reserved share data and high-skilled wage data from CES, to an expensed-based measure of the total compensation to human capitalists. Specifically, we compare our measure of total income to a measure based on accumulating the widely available accounting variable selling, general, and administrative expenses (SG\&A). As detailed in Eisfeldt and Papanikolaou (2013) and the associated Internet Appendix, this variable typically includes the salaries, wages, equity compensation and bonuses of firms' white-collar workers and managers. However, since SG\&A includes other expenses unrelated to employee compensation, we follow the approximation approach from the prior literature (e.g., Eisfeldt and Papanikolaou (2014)) and scale the total SG\&A expense by 0.3. Our second measure of human capitalist income shares is then constructed in each year by aggregating the firm-level observations of $30 \%$ of SG\&A to the industry level and then computing the ratio of industry-level $0.3 \times \mathrm{SG} \& \mathrm{~A}$ to industry-level value added $(0.3 \times \mathrm{SG} \& \mathrm{~A} / \mathrm{VADD})$. This share was $8 \%$ at the beginning of the sample period, and increases to $12 \%$ at the end of 2019 . As expected, given that wages have trended downward while equity compensation increased substantially, the SG\&A based measure increases from 1980 to 2019, but not as dramatically as the measure of equity compensation only.

Our reserved-share approach to measuring equity-based compensation using reserved share data has an important advantage over the expense-based measure. In particular, reserved shares are not affected by changes in expensing practices for stock options that occurred over our sample period. Equity-based compensation can be used effectively for retention and incentive purposes, but purely accounting-based motivations have also played a role. Historically, equity-based pay was not always expensed, or was expensed at a low value, thereby boosting profits. The Internet Appendix contains further details. The fact that reserved shares on the balance sheet are not impacted by changes in expensing practices leads us to use this measure as our baseline measure, with support from the expense-based measure.

Finally, we note that, in the cross section, the increase in equity-based compensation is even 
more pronounced for small firms (See the Internet Appendix) 15 Although our sample focuses primarily on publicly traded firms, the fact that human capitalists in smaller firms receive more equity-based compensation as a share of total sales than those of larger firms indicates that our time series for the share of $N G$ relative to value added could be an underestimate for the whole US economy, including private firms. This increase in equity-based compensation among smaller firms also enhances the divergence between the average and the aggregate total labor share, which is consistent with the evidence in Hartman-Glaser et al. (2019).

\subsection{Time Series Evidence: Main Facts}

Table 2 reports the summary statistics of the key variables for our analysis. Panel A reports averages over a longer sample from 1960 to 2019, and provides the summary statistics that can be used to interpret our cross section regression coefficients, while Panel B reports averages for each decade since 1980 to illustrate the main time series facts. Both panels show that including equity-based compensation is key to understanding the high-skilled labor share. The wage-only high-skilled labor share averages only $16.5 \%$ over the full sample, and only $11 \%$ over the most recent decade. The equity-pay share of value added is only $2.4 \%$ on average in the full sample back to 1960 , but increases to an average of $6 \%$ in the most recent decade. Thus, while the wage share of high-skilled labor declined, these workers have transformed into human capitalists - their equity pay has steadily increased over this same time period. Including equity pay, the total high-skilled labor share doesn't change very much; it averages $19 \%$ over the full sample and $17 \%$ in the most recent decade. Panel A also shows that investment goods prices declined substantially over the full sample, on average $0.76 \%$ annually. The correlation between human capitalists' income and investment goods prices is -0.91 from over this time period, which motivates our study of technical change as a driver of human capitalist income. As investment goods prices declined, the relatively flat share of human capitalists, relative to the declining share of low-skilled labor, is consistent with technological complementarity between high-skilled labor and capital, and substitutability between low-skilled labor and capital. We formalize this intuition in our structural model and estimation.

Figure 1 shows the time series of human capitalists' flow of equity-based compensation as a share

\footnotetext{
${ }^{15}$ Using the sample for which we have full Compustat coverage (1970-1995), we show that smaller firms (i.e., firms in the bottom quintile of the size distribution) offer $10 \%$ more equity-based compensation to employees relative to firms in the top quintile.
} 
of value added. Panel (a) of Figure 2 shows this series along with the time series of human capitalists' wage, and total (wages + equity), compensation as a share of value added. Strikingly, the sevenfold increase in equity-based compensation relative to value added (i.e., a roughly 7 percentage point increase from the 1960s to the end of the sample) almost completely reverses the downward trend in high-skilled labor's wage income share. In fact, Panel (b) of Figure 2 shows that the increase in equity-based compensation is strong enough to greatly dampen the decline in the overall labor wage share of value added. Including equity-based compensation cuts the measured decline in the total labor share in our sample by $32 \%$. Note that the wage-based labor share in the NBER-CES sample is lower than that for the overall economy for two reasons. It is manufacturing only (no services), and it does not include any fringe benefits or equity. Despite the lower level, the downward trend is consistent with the prior literature using other labor compensation data. In line with these facts, the human capitalists' ownership share (Figure 1) (i.e., shares reserved for employee equity-based compensation relative to total equity shares outstanding) also displays a pronounced upward trend, increasing from about $1 \%$ before the 1980 s to about $10 \%$ in 2010 s. The increase in the ownership share was not driven only by top executives' equity-based compensation, which was relatively stable at around $2.2 \%$ on average in the 1990s and 2000s based on ExecuComp data.

\subsection{Understanding the Underestimation of Equity Pay in Standard Data Sources}

Two key features of equity-based compensation lead to equity income being substantially underestimated in standard data sources such as the Bureau of Economic Analysis (BEA) and the Bureau of Labor Statistics (BLS). These two features are tax treatment and deferral. First, a sizable fraction (one third to one half) of equity-based compensation is classified as incentive-based, and is thus taxed as capital gains income rather than ordinary income. Second, even pay that is taxed as ordinary income is only taxed after it vests and is exercised, rather than at the time it is granted. While this would not result in mismeasurement if equity pay were constant, the very high observed growth in equity pay in recent decades means that exercised or vested equity pay severely underestimates current grants. That the majority of equity pay is missing from national accounting data is apparent by observing the publicly available IRS data which reports that the value of equity pay in W2 earnings was only $\$ 55$ Billion over the period 2008-2017 16 This is much smaller than our

\footnotetext{
${ }^{16}$ See Table $5 \mathrm{~A}$ of the publicly-available W2 data available at https://www.irs.gov/pub/irs-soi/17inallw2.xls.
} 
estimate of equity pay in the manufacturing sector only for the overlapping time period $(\$ 100 \mathrm{BN})$. We discuss the tax treatment and deferred nature of equity pay in turn, and then provide a stylized example to illustrate how these two features drive the underestimation of equity pay in standard data sources.

In most of the rest literature on the labor share, two main sources of payroll information are used: BEA-NIPA (e.g., Karabarbounis and Neiman (2014)) and the BLS Quarterly Census of Employment and Wages (QCEW) (e.g., Elsby, Hobijn, and Şahin (2013)). These measures include only payments to employees under plans that are taxed at the personal income tax rate and are either (a) reported as payroll by the employer on IRS Form 941 or (b) reported as wage income by the employee on his or her W-2 form $[17$ For this reporting to occur, the equity compensation must be both (i) issued under a plan which treats equity grants as ordinary income for tax purposes, and (ii) vested and exercised following deferral.

For measures of the labor share based on BEA-NIPA, the BEA technical methodology emphasize that their labor compensation series only includes vested and exercised non-qualified options. Specifically, they state that "wages and salaries in cash... includes employee gains from exercising non-qualified stock options (NSOs)... NSOs are regarded as additional, taxable, income at the time they are exercised; in contrast, incentive stock options do not require the reporting of additional income and are taxed as long-term capital gains when sold. The detailed data required for treating NSOs as compensation of employees when the options are granted (as the System of National Accounts (SNA) recommends) are not currently available. Instead, NSOs are valued at the time that they are exercised, and the difference between the market price at the time of the exercise and the price paid by the employee at the time of the exercise is recorded as wages and salaries." 18 For a discussion of the SNA recommendations and the BEA's research on NSOs, see Moylan (2000).

For measures of the labor share based on employer payroll records from the BLS (QCEW), as detailed at the BLS website (https://www.bls.gov/opub/hom/cew/data.htm), the QCEW comes from the administrative tax records of state unemployment insurance (UI) programs. It is similar to NIPA and only includes taxable wages. As such, it includes only the exercise value of non-qualified stock options (NSOs). In addition, as discussed in further detail in the BEA technical note, and

\footnotetext{
${ }^{17}$ See Hall and Murphy $(2003)$ for a detailed discussion of the tax treatment of stock options, and see Lebow et al. (1999) and Moylan (2000) for details on BLS and BEA treatment of stock options.

${ }^{10}$ See "Ch 10 compensation of employees," p. 2-3 of https://apps.bea.gov/national/pdf/chapter10.pdf
} 
in the related paper by Moylan (2000), internal BLS surveys indicate that UI records are likely to underestimate even the exercised value of NSOs. That reference states, at the top of page 3, that "In addition, although it appears that large technology firms are reporting as wages the exercise of employee stock options, it is not clear that all firms are doing so. Because the annual tax base for UI wages and salaries is capped at $\$ 7,000$ per employee, states may have little incentive to follow up with firms to ensure correct reporting of special compensation items."

Finally, two other measures of wages from the BLS have also been used in the macroeconomic literature on the labor share; namely, the employment cost index (ECI) and nonfarm compensation per hour $(\mathrm{CPH})$. The former excludes stock options altogether. The latter includes only exercised NSOs, as detailed in Table 1 of the FRB technical note Lebow et al. (1999). Additional details are provided in the Appendix, and the links to the relevant technical documentation also provide clear explanations for the treatment of equity compensation for each source. We provide a method for adjusting compensation in standard data sources to fully account for the flow of equity-based compensation, and describe the impact of including equity pay on the labor share based on BEA data, at the end of this section.

Equity Pay and Taxes Employers can adopt an equity compensation program by approving one of a variety of employee compensation plans, such as a stock option plan, a restricted stock unit (RSU) plan, an employee stock purchase plan (ESPP), or an employee stock ownership plan (ESOP), as well as by placing employee stock grants in retirement and 401(k) plans. For tax purposes, earnings from equity-based compensation may be treated either as income or as capital gains, depending on whether such compensation is derived from non-qualified or qualified plans, respectively. Equity pay that is derived from a plan that is qualified under the IRS code as incentivebased is tax-advantaged at the worker level, since the employee can, with proper execution, avoid being taxed at the ordinary income rate and instead pay only long-term capital gains taxes 19 Preferable personal tax treatment may be one reason that equity pay has grown in importance.

Qualified equity grants are never included in standard sources for labor compensation such as the BEA or BLS. We estimate that the fraction of equity grants which are qualified for tax purposes, and thus entirely excluded from standard sources, to be between one half and one third. Crimmel and Schildkraut (1999) document that about half of plans surveyed by the BLS offer incentive-based

\footnotetext{
${ }^{19}$ See https://www.irs.gov/taxtopics/tc427
} 
compensation that is qualified for tax purposes and excluded from standard sources. In ExecuComp data, which covers firms' most highly compensated employees, the fraction of equity compensation which is incentive-based and qualified is one third. Because there is a limit (currently $\$ 100,000$ ) on the maximum value of incentive-based options allowed under IRS rules, and it is more likely that executive (vs. non-executive) compensation exceeds this limit, we argue that one third is a lower bound on qualified equity pay for non-executive employees.

Vesting and Exercise Employees receiving equity-based compensation are granted promises of future equity shares, which can only be exercised or vested after a certain period of time has elapsed. In addition to complicating the matching of pay to the year in which labor was provided (and value added generated), the combination of deferral and the fast growth of equity pay means that even the portion of equity pay that is taxed at normal income rates and should appear on W2 tax returns is a small fraction of current new equity grants. Indeed, in ExecuComp data, vested and exercised options are an an order of magnitude smaller than the overall value of granted and unexpired stock options (at about $1 \%$ of stock market capitalization relative to $9 \%$, respectively; see Table 2).

A Simple Example The following stylized example illustrates the joint effects of qualified equity pay and the timing of new grants vs. exercise dates on the underestimation of equity pay in standard sources. Assume that total new grants relative to value added grows at an effective annual rate of $12 \%$ per year, which is the constant continuously compounded growth rate that connects the beginning and end points of our data on total new grants. Assume also that, conservatively, of the total, $2 / 3$ of grants are non-qualified and that $100 \%$ of grants are exercised immediately after a five year vesting period. Because the value of new grants grows each year at $12 \%$, and grants can only be exercised after the vesting period of 5 years, the value of vested and exercised non-qualified grants (i.e. the portion that might be counted in standard sources) is equal to only $37 \%$ of total current grants. With a constant growth rate, this fraction is also constant. It is important to note that, as it is $63 \%$ of a growing series, the part of equity compensation that is missing from standard labor share measures grows very substantially in levels in this example, as can be seen in Figure 3 . 
Figure 3: Equity-Based Compensation as a Fraction of Value Added

Stylized Example of Missing Equity Pay: We construct a stylized example to illustrate the effects of tax treatment and deferral on missing equity pay. We plot total grants (solid line), grants included in standard data sources (dotted line), and grants missing from standard data sources (dashed line). This example uses the observed share of new grants relative to value added in 1975 , and assumes that this share grows at a constant rate of $12 \%$, which results in grants as a share of value added which approximately match the empirical share in recent decades of about 6\%. From 1980 to 2019, the implied total grants are the top, solid line. The bottom, dotted, line denotes grants that could appear in standard labor data, i.e. non-qualifed, exercised grants. We assume that two thirds of grants are non-qualified, and that $100 \%$ of non-qualified grants are exercised five years after they are granted. The calibrated assumptions result in $63 \%$ of current grants being excluded from standard data sources, while a minority of $37 \%$ are included.

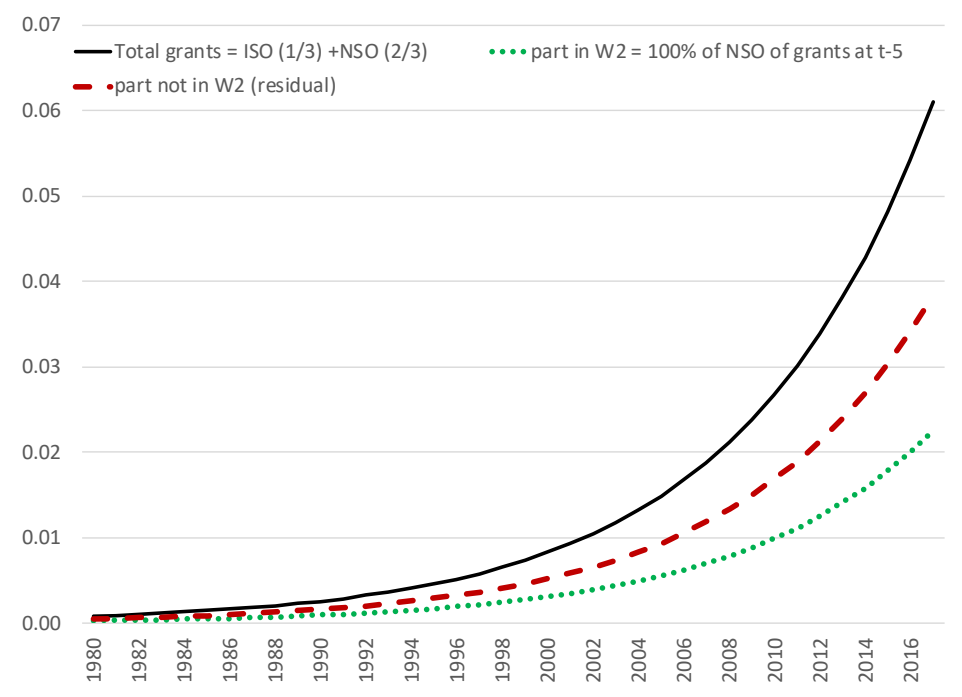

\subsection{Adjusting the BEA Manufacturing Labor Share}

In our main analysis we use NBER-CES payroll data, which only includes wages, to construct human capitalists' total income series. However, in most of the existing literature on the labor share, the standard data sources, from BEA (Karabarbounis and Neiman, 2014) or BLS (Elsby et al., 2013), are employed to construct labor share measures. As detailed in Section 2.3, compensation data from either of these two data sources only includes the fraction of equity-based compensation which is both exercised or unrestricted and non-qualified for tax purposes.

To evaluate the impact of including the equity-based compensation $(N G)$ on the labor share measures based on standard data sources (BEA), we must first estimate a series for wage-only compensation by subtracting income from exercised, non-qualified stock options. Otherwise, some equity pay would be double counted. In ExecutiveComp data, non-qualified equity-based grants are two thirds of total grants. Although it is likely that non-executives are eligible for a higher 
fraction of qualified grants because they are more likely to have equity compensation below the $\$ 100,000$ cap on qualified grants, we adopt the conservative assumption that two thirds of grants to all employees are non-qualified. We assume that the $100 \%$ of the non-qualified equity grants are exercised as soon as they are vested, and apply the average vesting period of 5 years.

Figure 4: Aggregate Labor Share in Manufacturing: Adjusting BEA Labor Share

The figure reports the aggregate labor share in manufacturing before and after the adjustment for NG. The dotted blue line is the aggregate wage income minus the estimate of the total value of exercised employee stock options. The dashed black line is the ratio of NG to value added. The total labor income share is the sum of the wage income share and the equity-based income share. Data source: Compustat Fundamental Annual (1960-1996), RiskMetrics (IRRC) (1996-2005), and NBER-CES Manufacturing Industry Database (1960-2011). The total manufacturing labor income and value added data is from KLEMS industry dataset. The non-financial corporate sector labor income and value added data is from NIPA Table 1.14. The sample period is from 1960 to 2019.

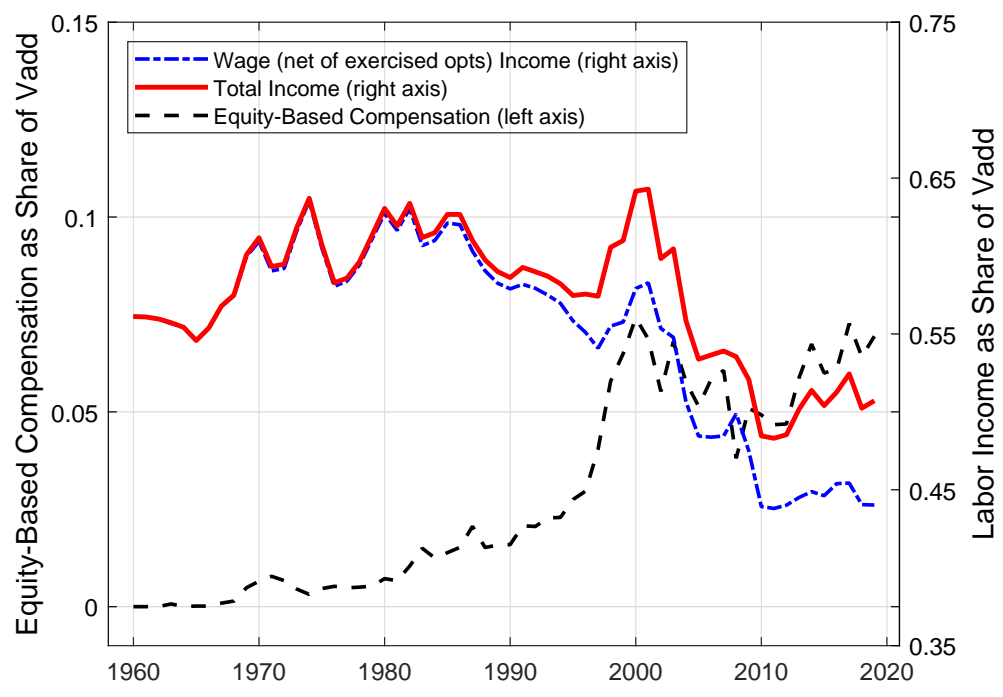

To construct the wage-only labor income in year $t$, we subtract the estimated amount of current equity grants that are included in the contemporaneous BEA income measure. Assuming all grants are exercised immediately after vesting for five years, $100 \%$ of two-thirds of equity grants (i.e. all grants that are non-qualified) from year $t-5$ appear in year $t$ BEA income ${ }^{20}$ Our estimates indicate that, due to deferral and the fact that one third of grants are qualified, only $35 \%$ of current equity grants are accounted for in the BEA data at any given date $t$. The total labor share is then the sum of estimated wage-only labor income plus the contemporaneous estimate of new grants relative to value-added.

\footnotetext{
${ }^{20}$ The BEA wage-only series is thus BEA compensation minus $2 / 3^{*} N G_{t-5}$.
} 
Figure 4 reports the aggregate BEA labor share after adjusting for equity-based compensation (NG) for the manufacturing industry (for which we hand-collected the equity pay data for the years after 2006). The manufacturing wage-only labor share declined by $17 \%$ since 1980 s, and including the equity-based compensation reduces the decline in the labor share based on the BEA manufacturing-sector data by $20 \%$. Although our adjustment focuses on the manufacturing industry broadly-defined, the inclusion of equity-based pay should still have large impact on the aggregate labor share given the evidence in Alvarez-Cuadrado et al. (2018) and (Aum and Shin, 2020) that the downward trend in the aggregate labor share since the 1980 is mainly driven by the decline of labor share in the manufacturing industry.

\subsection{Panel Data Evidence}

We next show that cross-industry and cross-firm evidence is consistent with (a) a substitution mechanism between human capital and labor and (b) complementarity between human capital and physical capital. Complementarity indicates that human capitalists' share of value added decline as costs of physical capital goods become cheaper. We first test whether trends in total human capitalists' share of value added are related to trends in investment goods prices at the industry level. The KaO (1999) cointegration test cannot reject the null hypothesis that there is no cointegration between the human capitalists' share of value added and industry-level investment goods prices 21 The evidence of cointegration between the human capital share and investment goods prices is consistent with industry-specific investment goods prices being the source of the trend in human capitalists' share of value added. Our regression results also support the idea that the share of equity based compensation relative to value added, and total human capitalists' share of value added, is strongly and statistically significantly negatively related to the industry-specific path of investment goods prices.

Table 3 reports industry-level multivariate regressions of the human capitalists' share in a given year on both the physical capital share and the unskilled labor share at the 4-digit SIC code level of industry aggregation.We follow Karabarbounis and Neiman (2014) and use investment relative

\footnotetext{
${ }^{21}$ The modified Dickey-Fuller t-statistics is 9.53 . We also perform another Engle-Granger based coningegration Pedroni test and Westerlund test. Under both tests, we can not reject the null hypotheses with all p-values equal to zero.
} 
to value added 22 Both the grant-based and the expense-based shares are significantly positively (negatively) correlated with physical capital share (unskilled labor share) within industry and over time.

Table 4 reports (4-SIC) industry-level regressions of income shares on investment goods prices. These regressions include year and industry fixed effects, and thus examine the change in industrylevel share variables across industries and years that were more vs. less exposed to the decline in capital goods prices, because the capital mix across capital types which experienced different price changes varies over time and across industries. If there is more complementarity between human capital and physical capital than that between human capital and labor, one should expect to see the total human capital share of value added negatively correlated with the investment goods prices, i.e., the coefficient of investment goods prices should be negative. The first three columns show that the share of value added represented by equity-based compensation, total human capitalist income, and the expense-based proxy for total human capitalist income are robustly negative and strongly statistically significant for all measures of human capitalists' income shares. The estimates are also economically significant, as they imply that a one standard deviation decline in investment goods prices is associated with up to about $9.4 \%$ of a standard deviation increase in the log human capitalists' income share (Column 2). Columns (4-6) examine the relation of wage shares and investment goods prices. Columns (4-5) show that there is a weak negative relation between the total wage share and investment goods prices, and a stronger positive relationship for the unskilled labor wage share across industries, suggesting substitution between unskilled labor and capital. Although not significant, the negative relation between the total wage share and investment goods prices aligns with the cross-country evidence in Karabarbounis and Neiman (2014). Column (6) shows that the decline in the wage share of high-skilled labor is negatively related to the investment goods prices in the cross-section of industries, indicating that the skilled wage share declined less in industries which faced larger declines in capital goods price, consistent with complementarity between high skilled labor and capital. Note that the coefficient on investment goods prices is much smaller in absolute value in Column (6) vs. Column (1), meaning that equity pay had an

\footnotetext{
${ }^{22}$ Steady state capital share is investment to value added ratio multiplied by a constant scalar at the steady state. $\frac{I}{Y}\left(\frac{1 / \beta-1+\delta_{k}}{\delta_{k}}\right)$. We assume the parameter $\beta, \delta_{k}$ is constant across industry at steady state. Hence, in the regression, this scalar is absorbed in the constant term. Note that in a model with constant growth path, $\frac{I}{Y}=\frac{r K}{Y}$ as long as the real interest rate equals the growth rate of GDP.
} 
increasing share of total pay in industries and years in which capital goods prices declined by more. Column (7) confirms this by showing that declining investment goods prices are correlated with a change in the structure of human capitalists' pay, with equity-based compensation increasing in importance, although the correlation is not statistically significant. Column (8) reports the significant negative relation between the ownership share (which corrects for generally rising share prices) and investment goods prices. A one standard deviation decline in investment goods prices is associated with up to about $8.2 \%$ of a standard deviation increase in the human capitalists' ownership share. Overall, the regression analysis confirms the negative time-series relation between investment goods prices and human capitalists' income and ownership shares.

Table 5 confirms the relation between investment goods prices and human capitalists' income and ownership shares at the firm level for specifications with industry fixed effects (Panel A) and firm fixed effects (Panel B). Columns (1-2) show that human capitalists' ownership shares increased more in firm-years with larger investment goods price declines. The relation between investment goods prices and the ownership share is also economically significant. We observe that a one standard deviation decline in investment goods prices is associated with an increase of about $10 \%$ of a standard deviation in the human capitalists' ownership share at the firm level, based on the estimate in Column (2). Using sales to proxy for value added in the firm-level data for which value added is not available, Columns (3-4) show that equity compensation to sales also increased more in firm-years with larger investment goods price declines. The coefficient estimate in Column (4) implies that a one standard deviation decline in investment goods prices is associated with an increase of about $2.6 \%$ of a standard deviation in the human capitalists' income share of sales at the firm level. Columns (5-6) show that the expense based measure of human capitalist income is also negatively related to investment goods prices at the firm level.

Next, we examine the growth of the human capitalists' share relative to the physical capital share as investment goods prices decline. This is an important motivation for complementarity between physical and human capital. Table 6 reports industry-level regressions of the growth of human capitalists' share in a given industry-year relative to the growth in the physical capital share on investment goods prices. The coefficient estimates for all measures of relative share changes are negative and statistically significant. A one standard deviation decline in investment goods prices is associated with $13 \%$ of a standard deviation faster growth (on average) of the human capitalists' 
share relative to the physical capital share (Column (4)). These changes in relative shares drive the identification in our structural analysis below.

We also confirm that our main results are robust to sharpening our measurement by using the more granular information on employee stock option grants that is available for the 1996-2005 period. Our baseline measure has the advantage of being available for a wide cross section of firms over a long time series. For the 1996-2005 period, we have reported data on the value of newly granted options and restricted stock, and we use this information to corroborate the relation between equity-based compensation from granted stock options and investment goods prices. In Panel A of Table 7, we confirm that the negative relation with investment goods prices also holds for an alternative measure of human capitalists' equity-based compensation: the (Black-Scholes) value of their earnings from stock option grants relative to the value added (sales) at the industry level (firm level) (Columns 1-2 and 3-4, respectively). Another concern is that our measures include the compensation of the very top executives and, as such, our results may be driven solely by this relatively small subset of human capitalists. Panel B of Table 7 shows that the negative relation with investment goods prices holds even after we net out the value of stock option grants for the top five executives. This means that the relation between declining investment goods prices and equitybased compensation is stronger for employees outside the C-suite 23 Thus, our results for human capitalists' income shares reflect the impact of broad-based employee stock-based compensation, and not executive pay.

Additional robustness checks appear in the Internet Appendix. In particular, employee stock compensation plans lead to the dilution of existing shareholders in the absence of a parallel repurchase plan. We show that the same relationships as in our main tables between human capitalist income and investment goods prices holds for the comparison between diluted and undiluted earnings per share, and stock repurchases. Both of these variables should be correlated with equity compensation grants at the firm level. We also show that our results on ownership shares are robust to expanding the sample to the entire public firm universe by including the non-manufacturing sectors, for which we do not have value added data. We also show that the cross-sectional results are robust to using a measure of employee wealth that includes the value of both new and past

\footnotetext{
${ }^{23}$ We take information on stock option grants for a firm's top five executives from ExecComp, which is a standard source.
} 
grants.

\section{Model}

In this section, we propose a simple framework to show that the stylized facts that describe factor shares in both the time series and in the cross section can be explained by a unified equilibrium macroeconomic model. Our model employs a CES production function with three inputs, physical capital, human capital, and (unskilled) labor. Human capital's participation constraint accounts for the fact that human capital may earn more than its marginal product in an economy with profits to be shared and outside options to be met. However, our results indicate that almost all (91\%) of equity compensation is earned in return for human capitalists' marginal product. Technological progress occurs via a standard shock to (physical) investment goods prices (see Greenwood et al. (1997), Papanikolaou (2011), and Kogan and Papanikolaou (2014)). We use our model to obtain quantitative estimates of the degree of complementarity between physical and human capital. We find that correcting human capitalists' income by including equity-based compensation is crucial for identifying complementarity between physical and human capital. Using wages only leads to the conclusion that physical and human capital are more substitutable than Cobb and Douglas (1928) when recent data is included. This section describes the model, and the following section discusses its estimation.

\subsection{The Economy}

The economy is populated by a continuum of symmetric firms that produce intermediate goods $j$ using both physical capital $k$ and human capital $h$. There are two sectors of households. One household sector, physical capitalists, denoted by $K$, owns physical capital and provides low-skilled labor, while the other household sector, human capitalists, denoted by $H$, produces human capital. There is no uncertainty in the economy, and the decline in investment goods prices is known by all agents in advance.

Final Goods Production Final goods are produced using a continuum of intermediate goods, $j$. Final goods production is perfectly competitive, and output is produced via a Dixit-Stiglitz 
aggregator of intermediate goods. We have,

$$
Y_{t}=\left[\int_{0}^{1} y_{j, t}^{\frac{1}{\epsilon_{t}}} d j\right]^{\epsilon_{t}}
$$

where $\epsilon_{t}>11^{24}$ is the elasticity of substitution between intermediate goods $j$.

Each intermediate good $j$ 's price is $p_{t}(j)$, which is endogenous and determined by solving for its demand from the final goods producer's profit maximization problem. Given perfect competition, there are zero profits for the final goods producer, hence we obtain the standard symmetric demand function for the intermediate goods $j$ :

$$
y_{j, t} \equiv D_{t}\left(p_{t}(j)\right)=Y_{t}\left(\frac{p_{t}(j)}{P_{t}^{Y}}\right)^{\frac{\epsilon_{t}}{1-\epsilon_{t}}}
$$

The final consumption good is the numeraire, and it has a price $P_{t}^{Y}=1$.

Intermediate Goods Production Production of intermediate goods requires both types of capital, $k$ and $h$, and also (unskilled) labor, $n$, supplied by the households in the $K$ sector 25 In this simple model, we assume that there are no adjustment costs associated either with physical capital investment or with adjusting labor. The required rates of return for physical capital and human capital are $R_{t}^{k}$ and $R_{t}^{h}$, respectively. Labor is compensated with a per-period market-clearing wage, $w_{t}$. Firms produce intermediate goods $j$ using $k, h$, and $n$ according to a constant-return-to-scale CES production function as in Krusell, Ohanian, Rìos-Rull, and Violante (2000):

$$
y_{j, t}=f\left(z_{t}, k_{t}(j), h_{t}(j), n_{t}(j)\right)=z_{t}\left[\alpha_{c}\left(\left(\alpha_{k} k_{t}(j)^{\rho}+\left(1-\alpha_{k}\right) h_{t}(j)^{\rho}\right)^{\frac{\sigma}{\rho}}+\left(1-\alpha_{c}\right) n_{t}(j)^{\sigma}\right]^{\frac{1}{\sigma}}\right.
$$

where $z_{t}$ represents the level of factor-neutral productivity and $\alpha_{i}, i=k, c$ are share parameters. The variable $\sigma$ governs both the elasticity of substitution $\left(\frac{1}{1-\sigma}\right)$ between physical capital and labor, and the elasticity of substitution between human capital and labor. The variable $\rho$ governs the elasticity of substitution $\left(\frac{1}{1-\rho}\right)$ between physical capital and human capital. A zero value for $\sigma$

\footnotetext{
${ }^{24}$ By assuming $\epsilon>1$, we obtain curvature in the production of final goods: Each type of intermediate good $j$ is required for final goods production.

${ }^{25}$ Alternatively, we can assume that labor is supplied either by the human capitalist or by both household sectors. This assumption does not affect the result for the labor share of income. The supply of labor in equilibrium is determined by the marginal cost of labor and the marginal benefit of consumption.
} 
or $\rho$ indicates the same degree of complementarity as Cobb-Douglas, and a value of 1 for $\sigma$ or $\rho$ indicates perfect substitution. A $\sigma>\rho$ indicates that physical capital is more complementary with human capital than with unskilled labor, and a negative $\rho$ indicates that the complementarity is greater than that of Cobb-Douglas.

The profit-maximizing intermediate goods sector is owned by both physical capitalists and human capitalists. We assume that physical capitalists operate the firms in the intermediate sector. They maximize their share of firm value $V^{k}(j)$ subject to the participation constraint of human capitalists. A residual fraction $\lambda$ of profits $\Pi_{t}(j)$ is owned by these physical capitalists. This fraction represents the remaining profits available for distribution after the necessary profit-sharing with human capitalists.

The profit-maximization problem $\mathcal{P}$ of each intermediate sector $j$ is:

$$
V_{t}^{k}(j)=\max _{p_{t}(j), k_{t}(j), h_{t}(j), n_{t}(j), y_{j, t}, \lambda} \lambda \cdot \sum_{t} \beta^{t} \Pi_{t}(j)=\lambda \cdot \Pi_{t}(j)+\beta \cdot V_{t+1}^{k}(j),
$$

subject to

$$
\begin{aligned}
\Pi_{t}(j) & =p_{t}(j) y_{j, t}-R_{t}^{k} k_{t}(j)-R_{t}^{h} h_{t}(j)-w_{t} n_{t}(j) \\
y_{j, t} & =p_{t}(j)^{\frac{\epsilon_{t}}{1-\epsilon}} Y_{t} \\
R_{t}^{h} h_{t}(j)+(1-\lambda) V_{t}(j) & \geq \mathcal{O}_{t}=R_{t}^{h} h_{t}(j)+\eta V_{t}(j),
\end{aligned}
$$

where (5) is the demand for intermediate goods $j$ from Equation (2), and (6) is the participation constraint for human capitalists. The total firm value is $V_{t}(j)=\sum_{s=t+1} \beta^{s} \Pi_{s}(j)$, which is the accumulated present value of the residual profits after the marginal products of capital and labor are paid. The fraction of firm value shared with human capitalists can be expressed as $V_{t}^{h}(j)=$ $(1-\lambda) V_{t}(j)$, which is the accumulated present value of profit-sharing that physical capitalists promised to human capitalists before production. Hence, $V_{t}^{h}(j)+V_{t}^{k}(j)=V_{t}(j)$ for $\forall j$. Since we will focus on a symmetric equilibrium, we will omit the index $j$ going forward.

Equation (6) describes the participation constraint for human capitalists. If human capitalists remain with their present firm, they receive their marginal product $R^{h} h$ as well as some promised share of the firm $(1-\lambda) V_{t}^{h}$. Firm owners set the latter component by adjusting $\lambda$ so that human 
capitalists' participation constraint is satisfied. This practice is consistent with observed corporate behavior, in which firms retain talent by granting deferred compensation in the form of restricted equity or unvested options. If human capitalists leave to start a new firm, we assume they will still receive their marginal product $R^{h} h$. Note that this marginal product can be paid with wages or with equity-based compensation. In addition, at their new firm, we assume that they will accrue a fraction $\eta$ of the new firm's value. Marginal products, which are the same regardless of whether the human capitalist remains with her existing firm or moves to a new firm, cancel out from both sides. Profit maximization by physical capitalists implies that (6) is always binding, and $\lambda=1-\eta$.

Note that the participation constraint (6) is expressed in terms of total firm value shared with human capitalists, so $V_{t}^{h}$ does not represent the flow compensation for human capitalists at period $t$. The share of firm value $1-\lambda$ is promised to human capitalists in period $t$, but the income of human capitalists due to retention motives should only include the incremental part (i.e., the flow) of the firm shares granted in period $t$. For measurement, it is useful to note that the change in the share of the firm owned by human capitalists is $\Delta V_{t}^{h} \equiv \Delta(1-\lambda) V^{t} \equiv \beta V_{t+1}^{h}-V_{t}^{h}$. Note that in a steady state, the change in shares of firm value $\Delta(1-\lambda) V_{t}$ would simply be the fraction of current profit $(1-\lambda) \Pi_{t}$, given the definition of $V_{t}$.

At this point, we take no stand on what fraction of human capitalists' marginal product is compensated using wages versus equity-based compensation. Equation (6) simply states that the total value allocated to human capitalists equals human capitalists' marginal product plus any additional shares of firm value needed to satisfy human capitalists' outside option and the participation constraint. In theory, both wages and equity-based compensation can be used for either the marginal product or the retention components of compensation. In practice, there are both accounting motivations and tax motivations for using equity-based pay, as well as retention and incentive reasons. To keep notation consistent, we denote the total flow of equity-based compensation as $E^{h}$, of which a fraction $\theta$ of $E^{h}$ is used to compensate human capitalists' marginal product, and $(1-\theta) E^{h}=\Delta(1-\lambda) V_{t}$ is then used for retention purposes. The marginal product $R^{h} h$ is the sum of the flow wage payment $w^{h}$ and the relevant fraction of equity-based compensation $\theta E^{h}$. We will use the information from the cross section to pin down the parameter $\theta$ in the second stage of our estimation.

Given $\eta$, the first-order conditions (w.r.t. $k, h$, and $n$ ) of the profit-maximizing choice yield a 
simple markup over marginal cost under the constant returns-to-scale technology: $p_{t} f_{k}=\mu_{t} R_{t}^{k}$, $p_{t} f_{h}=\mu_{t} R_{t}^{h}, p_{t} f_{n}=\mu_{t} w_{t}$, where the markup over marginal cost is $\mu_{t}=\epsilon_{t}$. The marginal product of $k$ is $f_{k}=z \alpha_{c} \alpha_{k}\left(\frac{y}{\Psi}\right)^{1-\sigma}\left(\frac{\Psi}{k}\right)^{1-\rho}$, the marginal product of $h$ is $f_{h}=z \alpha_{c}\left(1-\alpha_{k}\right)\left(\frac{y}{\Psi}\right)^{1-\sigma}\left(\frac{\Psi}{h}\right)^{1-\rho}$, where $\Psi=\left(\alpha_{k} k^{\rho}+\left(1-\alpha_{k}\right) h^{\rho}\right)^{\frac{1}{\rho}}$ and the marginal product of $n$ is $f_{n}=z\left(1-\alpha_{c}\right)\left(\frac{y}{n}\right)^{1-\sigma}$.

Agents This section describes the objective functions of the two sectors of households: A sector of physical capitalists, $K$, that supplies physical capital $k$ and labor $n$, and a sector of human capitalists, $H$, who supply $h$.

Physical capitalists own the production technology that produces physical capital $k$. We assume a linear technology for producing capital goods. Households can invest final output goods in order to increase the physical capital stock $k$ at prices determined by the level of investmentspecific technological change ${ }^{26}$ The law of motion for physical capital is

$$
k_{t+1}=\left(1-\delta_{k}\right) k_{t}+I_{t}^{k}, 0<\delta_{k}<1
$$

Investment decisions $I_{t}^{k}$ are made each period. The capital stock $k$ depreciates at the rate $\delta_{k}$. Define $p_{t}^{k}$ as the relative price of physical capital investment goods over the numeraire. The price of physical capital investment goods is $\tilde{p}_{t}^{k}=\frac{p_{t}^{k}}{z_{t}^{k}}$, and $z_{t}^{k}$ represents the investment-specific technological (IST) shock. Following Greenwood et al. (1997), $\tilde{p}_{t}^{k}$ represents the effective conversion rate of final output goods to equipment capital.

We assume that the physical capitalist sector owns the firms that produce intermediate goods, and it shares ownership of the profits $\Pi_{t}$ from this production. The physical capitalist sector also has access to risk-free assets $f_{t}$ with an interest rate of $R_{t}^{f}$. The representative physical capitalist maximizes her lifetime utility, defined as

$$
\max _{\left\{c_{t}, I_{t}^{k}\right\}_{t=0}^{\infty}} \sum \beta^{t} U^{k}\left(c_{t}^{k}, n_{t}\right)
$$

\footnotetext{
${ }^{26}$ We can extend the current setup to a general environment, as in Karabarbounis and Neiman (2014), which includes an intermediate goods sector for $k$.
} 
subject to the budget constraint:

$$
c_{t}^{k}+\tilde{p_{t}^{k}} I_{t}^{k}+f_{t+1}-\left(1+R_{t}^{f}\right) f_{t}=\int_{0}^{1} R_{t}^{k} k_{t}(j) d j+\lambda \Pi_{t}+w_{t} n_{t}
$$

where $\Pi_{t}=\int_{0}^{1} \Pi_{t}(j) d j=(\mu-1) \int_{0}^{1} p_{t}(j) y_{j, t} d j$.

Human capitalists own the production technology that produces human capital $h$, with the law of motion,

$$
h_{t+1}=\left(1-\delta_{h}\right) h_{t}+I_{t}^{h}, 0<\delta_{h}<1
$$

Investment, $I_{t}^{h}$, can be interpreted as investing in obtaining skills or improving knowledge.

The representative human capitalist maximizes expected lifetime utility, defined as

$$
\max _{\left\{c_{t}, I_{t}^{h}\right\}_{t=0}^{\infty}} \sum \beta^{t} U^{h}\left(c_{t}^{h}\right)
$$

subject to the budget constraint:

$$
c_{t}^{h}+I_{t}^{h}+f_{t+1}-\left(1+R_{t}^{f}\right) f_{t}=\int_{0}^{1} R_{t}^{h} h_{t}(j) d j+\beta V_{t+1}^{h}-V_{t}^{h},
$$

where the right-hand side states the sources of income of human capitalists. The marginal product of human capital is $R_{t}^{h} h_{t}$, and $\Delta(1-\lambda) V_{t} \equiv \beta V_{t+1}^{h}-V_{t}^{h}$ is the change in the share of the firm value that accrues to human capitalists from $t$ to $t+1$ in the steady state, in which the firm grows at the risk free rate. The change in the share of firm value accruing to human capitalists is implied by the participation constraint at consecutive dates.

Equilibrium We consider a symmetric equilibrium defined as follows:

Definition 1 A equilibrium in this economy is a sequence of prices $\left\{p_{t}(j)\right\}_{j}$ and quantities such that the following optimality and market clearing conditions hold: (a) Each household sector $i=k, h$

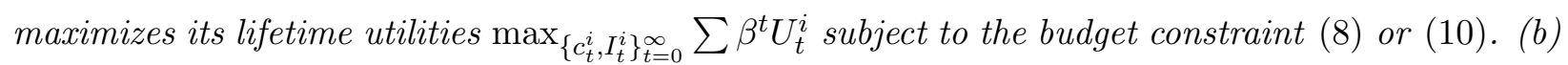
The owner of the final consumption goods sector solves the maximization problem $\mathcal{P}$. (c) The equilibrium is symmetric: $p_{t}(j)=P_{t}=1, k_{t}(j)=k_{t}, h_{t}(j)=h_{t}$ and $y_{j, t}=Y_{t}$. And, (d) The 
market clears: $Y_{t}=c_{t}^{k}+c_{t}^{h}+\tilde{p_{t}^{k}} I_{t}^{k}+I_{t}^{h}$.

Given the equilibrium definition, we obtain the standard inter-temporal Euler equations for consumption, investment, and labor supply:

$$
\begin{aligned}
1+R_{t+1}^{f} & =\frac{U_{c, t}^{i}}{\beta U_{c, t+1}^{i}}, \quad i=k, h \\
R_{t+1}^{k} & =\tilde{p_{t}^{k}} \frac{U_{c, t}^{k}}{\beta U_{c, t+1}^{k}}-\tilde{p}_{t+1}^{k}\left(1-\delta_{k}\right), \\
R_{t+1}^{h} & =\frac{U_{c, t}^{h}}{\beta U_{c, t+1}^{h}}-\left(1-\delta_{h}\right), \\
w_{t} & =\frac{U_{n, t}}{U_{c, t}} .
\end{aligned}
$$

Equation (12) and (13) determine the investment policies for $k$ and $h$. In general, households invest physical capital or human capital until the marginal benefits of capital $R_{t+1}^{i}, i=k, h$ equal the marginal costs of investment.

\subsection{Factor Shares of Income}

In this subsection, we describe the factor shares of income in our economy. The final output is distributed among three sectors: physical capitalists, human capitalists, and labor. Physical capitalists receive the rental income from physical capital, $R_{t}^{k} k_{t}$. They also receive the residual profit share after human capitalists' equity compensation is allocated. Human capitalists receive compensation equal to their marginal product plus any additional compensation necessary to satisfy their participation constraint. The sum of wages plus equity compensation is $R_{t}^{h} h_{t}+\Delta(1-\lambda) V_{t}$, though one cannot equate $R_{t}^{h} h_{t}$ to wages alone as equity can also be used to compensate marginal product. Finally, labor receives wages, $w_{t} n_{t}$. We have:

$$
\begin{aligned}
& R_{t}^{k} k_{t}+R_{t}^{h} h_{t}+w_{t} n_{t}+\lambda \Delta V_{t} \\
= & \underbrace{R_{t}^{k} k_{t}}_{\text {Physical Capitalists Income }}+\underbrace{R_{t}^{h} h_{t}+(1-\lambda) \Delta V_{t}}_{\text {Human Capitalists Income }}+\underbrace{\lambda \Delta V_{t}}_{\text {Profit Share }}+\underbrace{w_{t} n_{t}}_{\text {Low-skilled labor share }},
\end{aligned}
$$

where, in steady state total income equals $Y_{t}$ and $\Delta V_{t}=\Pi_{t}$. Note that, in our estimation, we use the full time series data rather than comparing steady states. 
The share of human capital income is then $\frac{R_{t}^{h} h_{t}+\Delta(1-\lambda) V_{t}}{Y_{t}}$, while the physical capitalists' income share is $\frac{R_{t}^{k} k_{t}}{Y_{t}}$. The residual share of profits $\lambda \Pi_{t}$ is the profit share. We note that, while it is not our main focus, our model highlights the distinction between shares of value added and shares of income. While shares of value added are based on current output and value added flows, shares of income can include compensation for contributions to firm value stemming from future output. Indeed, in a dynamic model with uncertainty (e.g., Hartman-Glaser et al. (2019)), ex ante income shares need not align with ex post shares of value added, and vice versa.

We now derive the relationship between the factor shares and the rate of return of each factor. For simplicity of exposition, we omit time subscripts. First, we characterize the relative shares of the two types of capital income $\frac{s_{k}}{s_{h}}$ :

$$
\frac{s_{k}}{s_{h}}=\frac{R^{k} k}{R^{h} h+\Delta(1-\lambda) V}=\frac{R^{k} k}{R^{h} h} \frac{R^{h} h}{R^{h} h+\Delta(1-\lambda) V}=\frac{R^{k} k}{R^{h} h} \omega_{R}
$$

where $\omega_{R} \equiv \frac{R^{h} h}{R^{h} h+\Delta(1-\lambda) V}$ is the fraction of human capital income that is the marginal product. The relative capital share of income is driven by two factors: the relative rental payment, or marginal product, of $k$ vs. $h, \mathbf{D} \equiv \frac{R^{k} k}{R^{h} h}$, and the composition of human capital income, $\omega_{R}$. When human capitalists' outside option $\eta$ is higher, human capitalists' income is driven more by the participation constraint share, $1-\omega_{R}$. The elasticity of substitution between $k$ and $h$ is crucial for the dynamics of relative rental payments and hence the relative share of capital income.

Next, we can derive the total physical plus human capital share $s_{k}+s_{h}$ as $1-s_{n}$ using the expressions of marginal products $f_{k}$ and $f_{h}$ :

$$
1-s_{n}=\frac{1}{\mu} \alpha_{c}^{\frac{1}{1-\sigma}} \alpha_{k}^{\frac{\sigma}{1-\sigma}} \mathbf{C}^{\frac{\sigma(1-\rho)}{1-\sigma}} R^{\frac{\sigma}{\sigma-1}}+1-\frac{1}{\mu}
$$

where $\mathbf{C}=\left(\alpha_{k}+\left(1-\alpha_{k}\right)\left[\frac{\left(1-\alpha_{k}\right) R^{k}}{\alpha_{k} R^{h}}\right]^{\frac{\rho}{1-\rho}}\right)^{\frac{1}{\rho}}[27$ The total capital share of income includes the profit share $1-\frac{1}{\mu}$ and total rental payments to $h$ and $k$, and depends on $\sigma$, the capital-labor complementarity. In general, a declining rental rate of capital $R^{k}$ along with capital-labor substitutability, $\sigma>0$, leads to an increase in overall rental payments to capital.

The dynamics of factor shares of value added are captured by Equations (12), (13), (15), and

\footnotetext{
${ }^{27}$ See the derivation in Appendix 6.3
} 
(16). We next confront this system with the data to estimate the production function parameters and examine their implications for the elasticities of substitution between the three input factors.

\section{Estimation}

In this section, we combine our model with the data to learn about the shape of the aggregate production technology. Specifically, we estimate the elasticity of substitution between $k$ and $h,(\rho)$, as well as the elasticity of substitution between labor and capital, $(\sigma)$ for all possible allocations of equity pay between marginal product and meeting the participation constraint. Finally, we combine a cross-section estimate of $\rho$ with our time series analysis to pin down the fraction of equity pay that is compensation for marginal product vs. retention considerations.

\subsection{Measurement Equations}

We start with the system of first-order conditions (15), and (16), with error terms $u_{t}$ and $\epsilon_{t}$ :

$$
\begin{aligned}
\frac{s_{k, t}}{s_{h, t}} & =\left(\frac{\alpha_{k}}{1-\alpha_{k}}\right)^{\frac{1}{1-\rho}}\left[\frac{R_{t}^{h}}{R_{t}^{k}}\right]^{\frac{\rho}{1-\rho}} \omega_{R, t}+u_{t} \\
1-s_{n, t} & =\frac{1}{\mu} \alpha_{c}^{\frac{1}{1-\sigma}} \alpha_{k}^{\frac{\sigma}{1-\sigma}} \mathbf{C}_{\mathbf{t}}^{\frac{\sigma(1-\rho)}{1-\sigma}} R_{t}^{k \frac{\sigma}{\sigma-1}}+1-\frac{1}{\mu}+\epsilon_{t},
\end{aligned}
$$

where the return to physical capitalists, $R_{t}^{k}$, and the return to human capitalists, $R_{t}^{h}$, are determined by households' intertemporal consumption and saving choices 12 and 13 . We estimate this system via maximum likelihood. Given that there are possible omitted variables that could cause serial correlation in the error terms, we allow the error terms to be serially correlated with auto correlation $\left[\psi_{u}, \psi_{\epsilon}\right]$. This procedure yields estimates for the constant elasticity parameters that enable the model to best fit the empirically observed trends in the relative capital share $\frac{s_{k, t}}{s_{h, t}}$ and the capital share $1-s_{n, t}$.

Equation (17) is key to identifying the parameter $\rho$. Dividing both sides by $\omega_{R}$ yields:

$$
\frac{s_{k}}{s_{h} \cdot \omega_{R}}=\frac{R^{k} k}{R^{h} h}=\left(\frac{\alpha_{k}}{1-\alpha_{k}}\right)^{\frac{1}{1-\rho}}\left(\frac{R^{h}}{R^{k}}\right)^{\frac{\rho}{1-\rho}} .
$$

The difference between the trends of rental payments to physical capital $R^{k} k$ and human capital $R^{h} h$ 
identifies the parameter $\rho$. To see the intuition, take logs of both sides of equation (19) and consider the resulting log difference on the right-hand side. The trend in the marginal return to capital $\frac{R_{t}^{h}}{R_{t}^{k}}$ equals the difference between the growth in the rental return to human capital investment $R^{h}$ and the trend of investment goods prices, scaled by $\frac{\rho}{1-\rho}$. As the relative price of physical investment goods trends downward, $R^{k}$ declines faster than the return to human capital investment $R^{h}$. Given that $\rho<1$, the relative share of physical capital compared to human capital $\frac{s_{k, t}}{s_{h, t} \omega_{R}}$ can decline in $\tilde{p^{k}}$ only if $\rho<0$ (i.e., only if $k$ and $h$ are complementary). In other words, the ratio between the two capital shares is crucial for understanding the degree of complementarity between these two types of capital in the production function.

The estimation requires data on the marginal product of human capital, $R^{h} h$, as an input to the left-hand side of Equation (19). In practice, what is observed is total human capitalists' income, which is composed of wages $w^{h}$ and equity-based compensation $E^{h}$. Each of these components may include both compensation for the marginal product $R^{h} h$ and any additional compensation required to satisfy human capitalists' outside option $\Delta(1-\lambda) V$. To account for this, we assume, as in the existing literature, that all wage compensation is due to human capitalists' marginal product. For equity-based compensation, we perform a series of estimations, assigning all values between $0 \%$ and $100 \%$ for the fraction $\theta$ of equity-based pay attributable to human capitalists' marginal product. We show that the structural estimation implies more complementarity than Cobb-Douglas between physical and human capital for all but small values of the fraction of equity-based pay that is used to compensate high-skilled labor for their marginal product.

Note that we are being conservative by not assigning all equity-based pay to human capitalists' marginal product. A reasonable baseline assumption would be that equity pay has simply replaced wages, but not increased overall pay. There are several reasons why firms might substitute away from wages and towards equity grants. First, equity-based pay is tax advantaged because qualified grants can avoid being taxed at income taxes. Second, before 2004, companies could use equitybased compensation without fully expensing it, thus boosting earnings ${ }^{28}$ Third, equity-based compensation is approved by the IRS as a justification for replacing dividends (taxed at the income tax rate) with repurchases (taxed at the capital gains rate). Finally, we note that equity-based compensation can be used to substitute equity-based compensation for wages due to incentive

\footnotetext{
${ }^{28}$ Expensing was recommended but voluntary starting in 1996 and became mandatory in 2004.
} 
alignment, retention motives, and relaxation of financial constraints by delaying a fraction of pay.

Rather than taking as a baseline that one hundred percent of equity-based pay is simply a substitute for wages, and used to compensate marginal product, we instead acknowledge that some reasons for using equity-based pay may break the standard assumption that marginal product and compensation are equated. The relative capital share on the left-hand side of Equation (19) can then be represented as follows:

$$
\frac{s_{k}}{s_{h} \omega_{R}}=\frac{R^{k} k}{R^{h} h}=\frac{R^{k} k}{w^{h}+\theta E^{h}} .
$$

The term $w^{h}$ is the measured flow wage income in the data, which represents only part of human capitalists' marginal product. The remainder of their marginal product is compensated with equity $\theta E^{h}$, where $E^{h}$ is the observed equity-based compensation. Hence, $R^{h} h=w^{h}+\theta E^{h}$ is the total compensation for human capitalists' marginal product, and $(1-\theta) E^{h}$ is any additional compensation, beyond the marginal product, necessary to satisfy human capitalists' outside option $\Delta(1-\lambda) V$. Our estimation strategy then proceeds in two steps: First, we estimate our model for all $\theta \in[0,1]$, and show the impact of varying $\theta$ on the estimated degree of complementarity between physical capital and human capital. Then, we exploit the cross-industry data to infer the value of $\theta$ from a cross section estimate of $\rho$.

The correlation between the rental rate of capital $k$ and the growth of the total capital share drives the sign of $\sigma$. To gain intuition, we can express the log growth of the total capital share as $s_{c}=1-s_{n}$, obtained from Equation 16$): \hat{s_{c}} \approx \frac{\sigma(1-\rho)}{1-\sigma} \hat{\mathbf{C}}+\frac{\sigma}{\sigma-1} \hat{R^{k}}$, where $\hat{s_{c}}$ denotes the change over time in the total capital share, for example. If capital and labor are substitutes, a downward-trend in the rental rate of physical capital drives up the total capital share. If physical and human capital are complements, declining capital goods prices can be accompanied by an increase in the demand for human capital despite the increase in its relative price.

\subsection{Estimation Results}

Equity-based compensation is critical when accounting for the rise in human capitalists' income share and when investigating the elasticity of substitution between physical capital and human capital. In this section, we first estimate our model using the time series data to show that it is crucial to include equity-based compensation for the identification of the complementarity 
between physical and human capital. When a small fraction of equity-based compensation is included, we find greater complementarity between physical and human capital than that implied by Cobb-Douglas. However, if equity compensation is ignored completely, we find instead greater substitutability. In the final estimation step, we use cross sectional data to estimate the elasticity of substitution between physical and human capital, and then we use that elasticity to pin down the fraction of equity pay that is due to human capitalists' marginal product.

We estimate our model to match the time series of factor shares for the sample period from 1980-2011. The reason for focusing on this time period is that the decline in investment goods prices $p_{t}^{k}$ started in the early 1980s, and the NBER-CES sample ends in 2011. The set of parameters that we estimate includes physical capital's share $\left(\alpha_{k}\right)$, total capital share $\left(\alpha_{c}\right)$, the elasticity of substitution (EOS) between $k$ and $h,(\rho)$, and the elasticity of substitution (EOS) between capital and labor $n,(\sigma)$. The parameters that govern the depreciation rate of capital $\delta_{k}$ and $\delta_{h}$ and the markup $\mu$ are calibrated.

Figure 5: Elasticities of Substitution and Equity-Based Compensation This figure shows estimates of parameters that govern the elasticity of substitution between physical and human capital $\rho$ and the elasticity of substitution between capital and labor, $\sigma$, when allowing for different values of $\theta$. In the left panel, the solid black line is the estimated $\rho$ using a 2-year moving average of the target moment in the data. In the right panel, the solid black line is the estimated $\sigma$ using a 2-year moving average of the target moment in the data. The estimates of the auto-correlation coefficients for the error terms $\psi_{u}$ and $\psi_{e}$ vary from 0.10 to 0.69 when varying $\theta$. Data source: Compustat Fundamental Annual, RiskMetrics (IRRC), and NBER-CES Manufacturing Industry Database. The sample period is from 1980 to 2011.
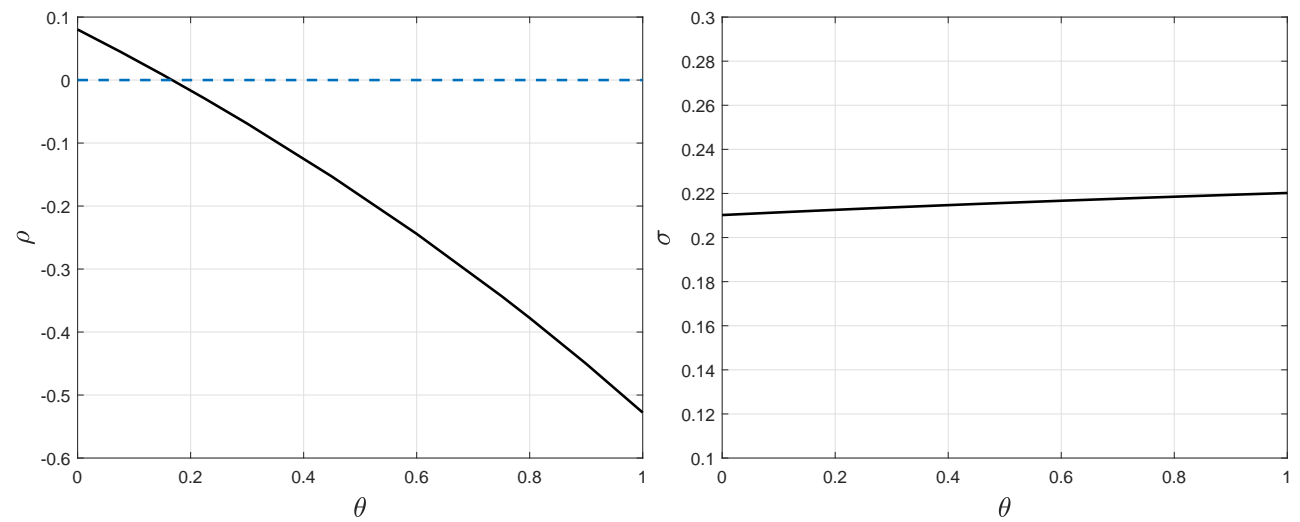

For the calibrated parameters, we set the depreciation rate of capital $\delta_{k}$ to the average investment rate in our sample (0.08). The variable $\delta_{h}$ is set to 0.15 , which is equal to the depreciation rate used by the BEA in its estimation of R\&D capital in 2006 (Eisfeldt and Papanikolaou (2013)). We set the markup parameter, $\mu$ to be constant at 1.3 throughout the sample period ${ }^{29}$ The returns

\footnotetext{
${ }^{29}$ De Loecker and Eeckhout (2017) estimated the average markup in the sample of publicly traded firms and showed
} 
to human and physical capitalists are determined by Equations 12 and $(13)$, where the interest rate $R_{f}$ is the time series of real rates over the sample period.

Recall that $\rho$ measures the degree of substitutability or complementarity between physical capital and human capital, while $\sigma$ measures the degree of substitutability or complementarity between physical capital and labor. Estimates below zero indicate more complementarity than Cobb-Douglas, while positive estimates indicate a greater degree of substitutability than CobbDouglas. Estimates of 1 indicate perfect substitutability. The left panel of Figure 5 displays the results for the estimate of $\rho$.

Our estimation shows that the parameter $\rho$ is highly sensitive to including even a small fraction of equity-based pay in the marginal product of human capitalists. When equity-based compensation is completely ignored $(\theta=0)$, the estimated parameter $\rho$ is positive, 0.08 , which implies more substitution between human capital and physical capital in the aggregate production function than Cobb-Douglas (the EOS is 1.09). As $\theta$ increases, the estimate of the elasticity of substitution parameter $\rho$ drops sharply. When only $16.7 \%$ of equity-based compensation is allocated to human capitalists' marginal product, the estimated elasticity of substitution $\rho$ becomes negative. In other words, omitting a small fraction of equity-based compensation in the human capital income share leads to an estimate of $\rho$ with the "wrong" sign. In addition, the decline in the estimate of $\rho$ accelerates quickly as $\theta$ increases.

By contrast, estimates of $\sigma$ do not vary significantly for different assumed values of $\theta$, as seen in the right panel of Figure 5, which plots the estimates of the elasticity of substitution between labor and capital. The average of estimate for $\sigma$ is 0.22 , which implies a strong degree of substitutability between capital and labor (an EOS of 1.28). Our estimate of the elasticity of substitution between capital and labor, $\sigma$, is similar to the findings in the existing literature. Karabarbounis and Neiman (2014) estimate that the EOS between capital and labor is 1.28 on average across countries. Krusell et al. (2000) report an EOS between capital and labor of 1.65 using their sample from 19631992. While substitution between capital and unskilled-labor can explain the declining labor share (unskilled and total) since the 1980s, equity-based compensation is crucial for understanding the elasticity of substitution between physical capital and human capital, especially in the last thirty

that the average markup has increased from 1.21 in the 1980 s to 1.45 around the mid-2000s. Karabarbounis and Neiman (2019) showed that the average increase in markup among the same sample is milder when including SG\&A as variable costs. 
years.

Thus far, we have remained relatively agnostic about what fraction, $\theta$, of equity-based compensation is attributable to compensation for human capitalists' marginal product. Our next estimation exercise exploits the cross section data to pin down our estimate of $\rho$, the degree of complementarity between physical and human capital. By using the estimate of $\rho$ from the cross section, we are able to provide an estimate of $\theta$ in our study of the time series. Our identification strategy is as follows: Recall the first-order condition (17), which captures the dynamics of the relative income shares of physical vs. human capital for each industry at each year. We take this equation to the data by taking logs on both sides and adding an i.i.d. error term:

$$
\log s_{h, j, t}-\log s_{k, j, t}=\frac{1}{1-\rho} \log \left(\frac{1-\alpha_{k}}{\alpha_{k}}\right)+\frac{\rho}{1-\rho} \log R_{j, t}^{k}-\frac{\rho}{1-\rho} \log R_{j}^{h}+\log \frac{1}{\omega_{R, t}}+e_{j, t}
$$

where $j$ denotes industry $j$. Since both $\omega_{R, t}$ and $R_{j}^{h}$ are unobservable, we need to assume that these variables are either fixed across time, or across industries to identify $\rho$ from the coefficient on $\log R_{j, t}^{k}$. We include both year fixed effects and industry fixed effects in the estimation, and assume that $\omega_{R, t}$ and $R_{j}^{h}$ are absorbed by industry fixed effects and year fixed effects. We interpret the specification as assuming that 1) $R_{j}^{h}$ is different across industries by identical over time; and 2) $\omega_{R, t}$ is identical across industries but varies over time. Note that because we identify $\rho$ from the coefficient on $\log R_{j, t}^{k}$, the alternative assumption that $R_{j}^{h}$ varies over time but is constant across industries, while $\omega_{R}$ is constant over time but varies across industries leads to the same estimation result for $\rho$.

We estimate (20) using the 4-SIC industry-level data for the sample period from 1980 to 2011 ${ }^{30}$ We find evidence of a strong degree of complementarity between physical and human capital in this cross section regression, consistent with our findings in Section 2.2. The estimated coefficient on $\log R_{j, t}^{k}$ is -0.34 and is highly significant (t-statistic of 2.64). This estimate implies that $\rho=-0.51$, and that the elasticity of substitution between physical capital and human capital is 0.66 . We note that our estimate of the elasticity of substitution between physical capital and human capital, using

\footnotetext{
${ }^{30}$ This empirical specification is the same as in Table 6 but with a different sample period. We do not use the longer sample for our estimate of $\rho$ in aggregate since investment goods prices were increasing in our sample prior to 1980. It is the start of the IT revolution around the time investment goods prices began declining that we argue drives complementarity between physical and human capital. For reference, the estimate of $\rho$ implied by the regression using data back to 1960 is -0.05 .
} 
data including equity-based compensation and more recent data, delivers a very similar parameter for complementarity to that reported in Krusell et al. (2000) (0.66) using wages only in data up to 1992. This is in stark contrast to the estimate we find using wage data alone in the full sample up to 2019 .

\section{Table 1: Two-Step Estimation}

This table reports estimated parameters from the two-step estimation. As the first step, we estimate the first-order condition 20]:

$$
\log s_{h, j, t}-\log s_{k, j, t}=\frac{1}{1-\rho} \log \left(\frac{1-\alpha_{k}}{\alpha_{k}}\right)+\frac{\rho}{1-\rho} \log R_{j, t}^{k}-\frac{\rho}{1-\rho} \log R_{j}^{h}+\log \frac{1}{\omega_{R, t}}+e_{j, t}
$$

where $j$ stands for 4-SIC industry $j$. We estimate a panel regression with industry and year fixed effects. We identify $\rho$ from the coefficient of $\log R_{j, t}^{k}$, and then infer $\theta$, the fraction of equity-based compensation due to human capitalists' marginal product given the mapping between $\rho$ and $\theta$ plotted in Figure 5 Second, given the value of $\theta$, we estimate the system of equations 17 and (18) using MLE on time series data. The table below reports the estimated parameters from the second estimation. We calibrated the following parameters: $\delta_{k}=0.08, \delta_{h}=0.15, \mu=1.3$. We feed in the observed $R_{f}$ using the time series of the real interest rate over the sample period. Human capitalists' income share is measured as the ratio of (wage income $+N G$ ) to value added in this estimation. The estimated serial correlations in the error terms are $\psi_{u}=0.32$ and $\psi_{e}=0.35$. The sample period is from 1980 - 2011. Standard errors are in parentheses. Implied elasticities between human and physical capital, and between all capital and labor, respectively, are given in the last row.

\begin{tabular}{ccccc}
\hline$\theta$ & $\rho$ & $\alpha_{k}$ & $\alpha_{c}$ & $\sigma$ \\
\hline 0.98 & -0.51 & 0.27 & 0.61 & 0.22 \\
- & $(0.19)$ & $(0.01)$ & $(0.10)$ & $(0.12)$ \\
\hline \hline & $\frac{1}{1-\rho}=0.66$ & & & $\frac{1}{1-\sigma}=1.28$ \\
\hline
\end{tabular}

Using this estimate of $\rho$, we can back out the fraction of equity-based compensation allocated to human capitalists' marginal product, $\theta$, from the estimation results in Figure 5 . As can be seen in the figure, the estimate of $\rho$ from the cross section of -0.51 implies that $\theta$ is $98 \%$. We argue that this estimate is intuitive. It seems reasonable that, rather than increasing pay overall, firms have substituted equity-based pay for wages due to its desirable tax, accounting, incentive, and retention characteristics. Table 1 presents the complete two-step estimation results, and, using the estimate of $\theta=98 \% 31$

\footnotetext{
${ }^{31}$ The resulting model fit is shown in the Internet Appendix, Figure IA6
} 


\section{Conclusion}

Including equity-based compensation in human capitalists' total labor income is critical for accurately measuring human capitalists' contribution to economic activity as well as their share of income. In recent data, $36 \%$ of compensation to high-skilled labor appears in the form of equitybased pay. Standard data sources severely understate this compensation, due to its standard deferral, and to unique tax treatment at both the firm level and the individual level. We employ data from firms' SEC filings to overcome this measurement challenge. Using only wages to measure the high-skilled labor share leads to a puzzling lack of complementarity between declining capital goods prices, mainly driven by e-capital, and high-skilled labor. A comprehensive measure of human capitalists income essentially reverses an otherwise declining trend in the high-skilled labor share and reduces the decline in the overall labor share by $32 \%$. 


\section{References}

Aboody, D., Barth, M. E., Kasznik, R., 2006. Do firms understate stock option-based compensation expense disclosed under sfas 123? Review of Accounting Studies 11, 429-461.

Acemoglu, D., 2002. Technical Change, Inequality, and the Labor Market. Journal of Economic Literature 40, 7-72.

Acemoglu, D., Dorn, D., Hanson, G. H., Price, B., et al., 2014. Return of the solow paradox? it, productivity, and employment in us manufacturing. American Economic Review 104, 394-99.

Acemoglu, D., Restrepo, P., 2019. Automation and new tasks: How technology displaces and reinstates labor. Journal of Economic Perspectives 33, 3-30.

Alvarez-Cuadrado, F., Van Long, N., Poschke, M., 2018. Capital-labor substitution, structural change and the labor income share. Journal of Economic Dynamics and Control 87, 206-231.

Atkeson, A., 2020. Alternative facts regarding the labor share. Review of Economic Dynamics 37, S167-S180.

Aum, S., Shin, Y., 2020. Why is the labor share declining? Tech. rep., Federal Reserve Bank of St. Louis Review.

Autor, D., 2019. Work of the past, work of the future. Tech. rep., MIT.

Autor, D., Dorn, D., Katz, L. F., Patterson, C., Reenen, J. V., 2017. Concentrating on the fall of the labor share. Working Paper 23108, National Bureau of Economic Research.

Autor, D. H., 2014. Skills, education, and the rise of earnings inequality among the "other 99 percent". Science 344, 843-851.

Bachelder, J. E., 2014. What has happened to stock options? Harvard Law School Forum on Corporate Governance and Financial Regulation .

Barkai, S., 2017. Declining labor and capital shares, $W$ orking Paper, University of Chicago.

Becker, R., Gray, W., Marvakov, J., 2013. Nber-ces manufacturing industry database. Working paper, National Bureau of Economic Research.

Benzell, S. G., Brynjolfsson, E., 2019. Digital abundance and scarce genius: Implications for wages, interest rates, and growth. Working Paper 25585, National Bureau of Economic Research.

Berman, E., Bound, J., Griliches, Z., 1994. Changes in the demand for skilled labor within us manufacturing: evidence from the annual survey of manufactures. The Quarterly Journal of Economics 109, 367-397.

Bhandari, A., McGrattan, E. R., 2020. Sweat equity in us private business. Quarterly Journal of Economics .

Black, F., Scholes, M., 1973. The pricing of options and corporate liabilities. Journal of Political Economy 81, 637-654.

Caicedo, S., Robert E. Lucas, J., Rossi-Hansberg, E., 2016. Learning, career paths, and the distribution of wages. Working Paper 22151, National Bureau of Economic Research. 
Caunedo, J., Jaume, D., Keller, E., 2019. Occupational exposure to capital-embodied technology. Tech. rep., Society for Economic Dynamics.

Cobb, C. W., Douglas, P. H., 1928. A theory of production. The American Economic Review 18, 139-165.

Crimmel, B. L., Schildkraut, J. L., 1999. National compensation survey collects test data on stock option plans. Compensation and Working Conditions pp. 17-20.

Cummins, J. G., Violante, G. L., 2002. Investment-specific technical change in the united states (1947-2000): Measurement and macroeconomic consequences. Review of Economic Dynamics 5, $243-284$.

De Loecker, J., Eeckhout, J., 2017. The rise of market power and the macroeconomic implications. Working Paper 23687, National Bureau of Economic Research.

Eisfeldt, A. L., Papanikolaou, D., 2013. Organization capital and the cross-section of expected returns. The Journal of Finance 68, 1365 - 1406.

Eisfeldt, A. L., Papanikolaou, D., 2014. The value and ownership of intangible capital. American Economic Review 104, 189-94.

Elsby, M. W., Hobijn, B., Şahin, A., 2013. The decline of the us labor share. Brookings Papers on Economic Activity 2013, 1-63.

Farhi, E., Gourio, F., 2018. Accounting for macro-finance trends: Market power, intangibles, and risk premia. Brookings Papers on Economic Activity pp. 147-223.

Frydman, C., Jenter, D., 2010. Ceo compensation. Working Paper 16585, National Bureau of Economic Research.

Frydman, C., Papanikolaou, D., 2015. In search of ideas: Technological innovation and executive pay inequality. NBER Working Papers 21795, National Bureau of Economic Research, Inc.

Frydman, C., Saks, R. E., 2010. Executive compensation: A new view from a long-term perspective, 1936-2005. The Review of Financial Studies 23, 2099-2138.

Gabaix, X., Landier, A., 2008. Why has ceo pay increased so much?*. The Quarterly Journal of Economics 123, 49-100.

Gabaix, X., Lasry, J.-M., Lions, P.-L., Moll, B., 2016. The dynamics of inequality. Econometrica $84,2071-2111$

Greenwald, D. L., Lettau, M., Ludvigson, S. C., 2019. How the wealth was won: Factors shares as market fundamentals. Tech. rep., National Bureau of Economic Research.

Greenwood, J., Hercowitz, Z., Krusell, P., 1997. Long-Run Implications of Investment-Specific Technological Change. American Economic Review 87, 342-62.

Hall, B. J., Liebman, J. B., 1998. Are ceos really paid like bureaucrats? The Quarterly Journal of Economics 113, 653-691.

Hall, B. J., Murphy, K. J., 2003. The trouble with stock options. Journal of Economic Perspectives $17,49-70$. 
Hartman-Glaser, B., Lustig, H., Xiaolan, M. Z., 2019. Capital share dynamics when firms insure workers. The Journal of Finance 74, 1707-1751.

Jaimovich, N., Rebelo, S., Wong, A., Zhang, M. B., Forthcoming. Trading up and the skill premium. NBER Macroannual .

Kao, C., 1999. Spurious regression and residual-based tests for cointegration in panel data. Journal of Econometrics 90, 1-44.

Kaplan, S. N., Rauh, J., 2010. Wall street and main street: What contributes to the rise in the highest incomes? The Review of Financial Studies 23, 1004-1050.

Karabarbounis, L., Neiman, B., 2014. The global decline of the labor share. The Quarterly Journal of Economics 129, 61-103.

Karabarbounis, L., Neiman, B., 2019. Accounting for factorless income. NBER Macroeconomics Annual 33, 167-228.

Kehrig, M., Vincent, N., 2020. The micro-level anatomy of the labor share decline. The Quarterly Journal of Economics .

Kogan, L., Papanikolaou, D., 2014. Growth opportunities, technology shocks, and asset prices. The Journal of Finance 69, 675-718.

Koh, D., Santaeulàlia-Llopis, R., Zheng, Y., 2020. Labor share decline and intellectual property products capital. Econometrica 88, 2609-2628.

Koh, D., Santaeulàlia-Llopis, R., Zheng, Y., 2016. Labor Share Decline and Intellectual Property Products Capital. Working Papers 927, Barcelona Graduate School of Economics.

Krusell, P., Ohanian, L. E., Rìos-Rull, J.-V., Violante, G. L., 2000. Capital-Skill Complementarity and Inequality: A Macroeconomic Analysis. Econometrica 68, 1029-1054.

Lawrence, R. Z., 2015. Recent declines in labor's share in us income: A preliminary neoclassical account. Working Paper 21296, National Bureau of Economic Research.

Lebow, D. E., Sheiner, L., Slifman, L., Starr-McCluer, M., 1999. Recent trends in compensation practices. Finance and Economics Discussion Series 1999-32, Board of Governors of the Federal Reserve System (US).

Lemieux, T., MacLeod, W. B., Parent, D., 2009. Performance pay and wage inequality. The Quarterly Journal of Economics 124, 1-49.

McGrattan, E. R., 2020. Intangible capital and measured productivity. Review of Economic Dynamics 37, S147-S166.

McGrattan, E. R., Prescott, E. C., 2010. Unmeasured investment and the puzzling us boom in the 1990s. American Economic Journal: Macroeconomics 2, 88-123.

Moylan, C., 2000. Treatment of employee stock options in the u.s. national economic accounts. Bea papers, Bureau of Economic Analysis.

Ohanian, L. E., Orak, M., Shen, S., 2021. Revisiting capital-skill complementarity, inequality, and labor share. Tech. rep., National Bureau of Economic Research. 
Papanikolaou, D., 2011. Investment shocks and asset prices. Journal of Political Economy 119, 639-685.

Pierce, J. R., Schott, P. K., 2016. The surprisingly swift decline of us manufacturing employment. American Economic Review 106, 1632-62.

Piketty, T., 2014. Capital in the 21st century. Cambridge: Harvard University .

Rognlie, M., 2015. Deciphering the fall and rise in the net capital share: Accumulation or scarcity? Brookings Papers on Economic Activity pp. 1-54.

Smith, M., Yagan, D., Zidar, O., Zwick, E., 2018. Capitalists in the twenty-first century. NBER Working Paper 25442 .

Smith, M., Yagan, D., Zidar, O. M., Zwick, E., 2021. The rise of pass-throughs and the decline of the labor share. Tech. rep., National Bureau of Economic Research.

Stokey, N. L., 2016. Technology, skill and the wage structure. Working Paper 22176, National Bureau of Economic Research. 


\section{Appendix}

\subsection{Discussion of Equity-Based Compensation in the Data and Literature}

In this section, we establish facts about the measurement of equity-based compensation. First, we document that the CES wages used in this paper are wages only. The Census form used to collect the responses that constitute the CES data is at

https ://www. census.gov/programs-surveys/asm/technical-documentation/questionnaire/ 2019-annual-survey-of-manufactures-forms.html and we confirmed this with the contacts listed at https://www .nber.org/research/data/nber-ces-manufacturing-industry-database

We use the answer to the following question:

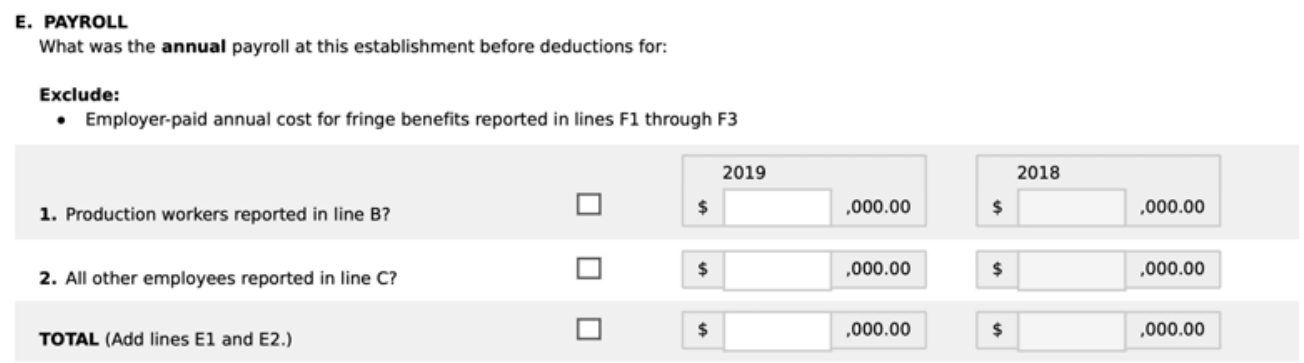

Note that the form explicitly states that benefits reported in lines F1 to F3 should be excluded from part E, payroll, which is the CES variable "PAY" which we use to measure wages. And, in the text preceding question F, the form states to "Include: Spread on stock options that are taxable to employees at this establishment as wages". Stock options are included in question F3, which can be downloaded at the link above. Question $\mathrm{F}$ is preceded by the following instructions:

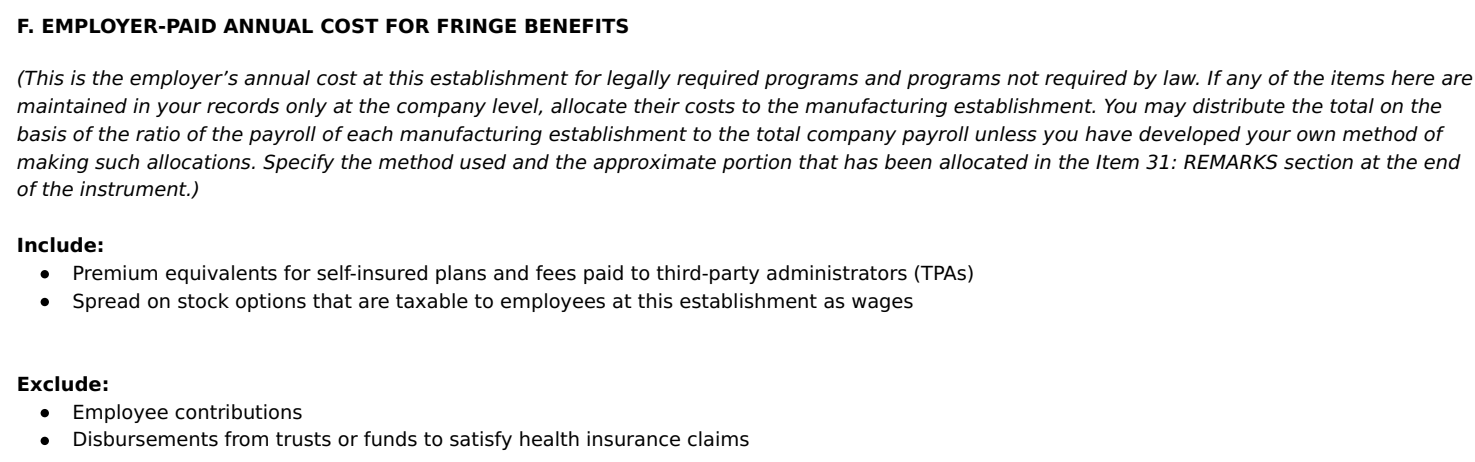

Thus, the CES data provide a "wages only" labor series. This is one of the reasons that the labor share using this data is lower than in other standard sources, though the downward trend is shared with standard labor share series.

The main text (Section 2.3 provides detailed documentation of the fact that existing data sources (based on BEA and BLS statistics) previously employed in the literature to measure the labor share include only a small fraction of equity-based compensation. For inclusion in standard sources based on income tax data records, equity pay must satisfy both of the following two criteria. First, the pay must be non-qualified for tax purposes, since pay under qualified plans allow for taxation at the lower capital gains tax rate ${ }^{32}$ Second, the pay must be both vested (or unrestricted) and exercised, meaning that current tax data reflects only exercised grants from five or more years ago. As detailed in Section 2.3, given the fast growth of equity pay, by the time exercised grants appear

\footnotetext{
${ }^{32}$ Qualifying dispositions, or those held by a retained employee for a sufficient time period, are reported on Schedule $\mathrm{D}$ and Form 8949.
} 
in income tax returns these past grants are a small fraction of the current flow of new equity pay grants. Additional email communications with the BEA and BLS staff are available upon request.

The advantage of the reserved share measure of equity-based pay over an expense-based measure is that it is not affected by changes in accounting rules. Starting from 1996, and up to 2004, the Financial Accounting Standards Board (FASB) recommended that firms expense compensation options using fair value (usually, Black-Scholes). However, this was only a recommendation, and firms could and did value options at the intrinsic value, which is zero if options are granted at the money. By doing so, firms boost current earnings. Due to strong incentives to inflate earnings, there is still substantial evidence in the accounting literature (eg. Aboody et al. (2006)) that firms continued to substantially undervalue their equity pay even after 2004 when FASB began requiring valuation at fair value under rule FAS 123R. In general, the value of employee stock options is reported on financial reports as a compensation expense that is spread over the period of vesting, rather than being expensed at the time it is granted 33

\subsection{Data Construction}

\subsubsection{Data Source}

The sample for income shares and investment goods prices Our main source data for constructing factor shares is the NBER-CES Manufacturing Industry Database. The NBER-CES Manufacturing Industry Database covers 4-digit SIC code-level information from 1960-2011 on output, employment, payroll, investment goods prices, and value added. All variables are defined at an annual frequency. We extend the time series for value added and aggregate payroll for the period 2012 - 2019 as follows: We obtain the growth rates of manufacturing value added and employee compensation from the NIPA tables available from the BEA, and compute the growth rates for value added and payroll for the industries comprising the manufacturing sector. We then project the CES data forward using these growth rates and the CES data from the end of our sample.

For corporate income shares (e.g., physical capital share, SG\&A share) and other firm-level variables, we obtain the data from the Compustat Fundamental Annual dataset from 1960-2019. We include only the manufacturing firms (SIC codes 2001 - 3999) to match the sectors covered by the NBER-CES sample.

Our main analyses are conducted in the merged sample of the public-firm data (Compustat, RiskMetrics, and hand-collection) and the NBER-CES Manufacturing Industry Database. This merged sample covers 5,271 firms and 133 of industries (4-SIC) from 1960-2019.

The sample for reserved shares We obtain the data for reserved shares from publicly-traded firms' accounting statements, which we gather from three sources: (a) the Compustat Fundamental Annual 1960-1995, (b) RiskMetrics 1996-2005, which covers firms from the S\&P 500, S\&P midcap, and S\&P smallcap indices, (c) hand-collected data 2006 - 2019 from 10k filings and proxy statements. We restrict our sample to U.S. companies with headquarters located in the U.S., and with a native currency code of U.S. dollars. We also restrict the sample to public firms traded in the major exchanges: New York Stock Exchange, American Stock Exchange, NASDAQ-NMS Stock Market, Midwest Exchange (Chicago) and Pacific Exchange. We exclude companies that trade ADRs (American Depositary Receipts).

\footnotetext{
${ }^{33}$ For example, if the vesting period is five years, one fifth of the value calculated at the time of the grant is expensed for each of the next five years.
} 
Merged Sample We merge the public firm and NBER-CES databases using four-digit SIC codes. Since we only observe value added at the industry level, we exclude industries (4-SIC) which have one or fewer firms in the NBER-CES-public-firm merged sample. In addition, to adjust for the differential coverage of the NBER-CES data covering all firms public and private, and the publicfirm dataset covering only public firms (and possibly including some pay to employees abroad), we scale our new grant series by the ratio of sales in Compustat to the ratio of sales in the NBER-CES data at the four-digit SIC code industry level. Specifically, for each year and in each industry $j$, we construct the scaling factor given by: Scale $_{j, t}=\frac{\sum_{j \in \text { Compustat }_{\text {Sales }}, t}}{\sum_{j \in \text { NBER-CES }} \text { Shipment }_{j, t}}$. We aggregate the firm-level value of $N G_{k, t}$ to the industry-level $\tilde{N G_{j, t}}$ by summing up over firms, $\tilde{N G_{j, t}}=\sum_{k \in \text { ind } j} N G_{k, t}$. We match the industry aggregate in public-firm data to the industry aggregate in the NBER-CES data by dividing the industry-level $\tilde{N} G_{j, t}$ by the industry-level scaling factor $S_{c a l e} e_{j, t}$. The adjusted industry aggregate we use in our analysis is $N G_{j, t}=\frac{\tilde{N G_{j, t}}}{S c a e_{j, t}}$. We construct the industry-level share of income from equity compensation as the ratio of industry-level $N G_{j, t}$ to industry-level value added.

\subsubsection{Variable Definitions and Construction}

Reserved shares (RS). Common shares reserved for conversion and future grant of employee stock options, which are defined as follows:

1. 1960-1983: CSHR (common shares reserved for conversion total) - DCPSTK (preferred stocks and convertible debt) (Compustat Fundamental Annual)

2. 1984-1995: CSHRO (common shares reserved for stock options conversion). The Compustat manual states "This item represents shares reserved for stock options outstanding as of yearend plus options that are available for future grants." During this period, there are separate data items for preferred stock and convertible bonds, as well as the data item for total common shares reserved for conversion (CSHR).

3. 1996-2005: Total available shares for future grants of employee equity-based compensation + total shares reserved for outstanding employee stock option grants (RiskMetrics)

4. 2006-2019: Total shares reserved for both outstanding employee equity-based compensation (options, warrants and stock grants) and future grants of equity-based compensation. (Handcollected data from SEC filings on Edgar)

Ownership share. The employee-owned fraction of firms is calculated as the value of reserved shares (RS) divided by stock market capitalization.

Value Added We obtain the value added series from NBER-CES dataset from 1960 - 2011, and extend the data to 2019 using BEA NIPA data as described above.

Human capital share. The total income to human capitalists as a share of value added.

1. Grant-based measure. Total human capital income includes the wage income of high-skilled human capitalists and their equity-based compensation. Sample period is 1960-2019.

- Human capital wage share: skilled workers' wages/value added 
- Equity-based compensation share: $\mathrm{NG}=$ (number of reserved shares $\times$ current stock price)/(weighted average granting period of six years). Equity-based compensation share $=\mathrm{NG} /$ value added.

- Total human capital share $=($ skilled wages $+\mathrm{NG}) /$ value added

2. Expense-based measure (i.e., selling, general, and administrative expenses). Sample period is 1960-2019. Industry-level SG\&A share: 30\% of SG\&A (Compustat) divided by value added (NBER-CES).

Physical capital share. Investment (NBER-CES) divided by value added (NBER-CES). This is a 4-digit SIC code-level variable available from NBER-CES from 1960-2011 and extended using BEA NIPA as described above.

Unskilled and total labor share. The unskilled labor share is a 4-digit SIC code-level variable available from NBER-CES from 1960-2011 and extended using BEA NIPA as described above.

1. Unskilled labor share: unskilled wages (production labor payroll)/value added (NBER-CES)

2. Total labor share $=$ total human capital share + unskilled labor share

Constructing the New Grant Series In this section, we provide a formal derivation of our baseline measure for the annual flow of deferred compensation. Our baseline measure is a fraction of the shares reserved for employee compensation, since the stock of reserved shares is available for a wide cross section of firms and a long time series of 60 years from 1960-2019. We calibrate our measure to RiskMetrics data, which contain information on both reserved shares and share-based employee compensation grants for the period 1996-2005. We also perform several robustness checks on this measure. Our measure is conservative, in the sense that we do not include capital gains or losses on share-based compensation that is granted but not vested, and share values have increased substantially, on average, over our sample (see Hall and Liebman (1998)).

We start with the following law of motion for the stock of reserved shares:

$$
R S_{t+1}=R S_{t}+N R S_{t}-E X C_{t}-E X P_{t},
$$

where $R S_{t}$ denotes reserved shares at the beginning of period $t$, and $R S_{t+1}$ is the stock of reserved shares at the beginning of period $t+1$. As is standard for the law of motion of any stock, there is both "investment" in the stock as well as "depreciation." Here, investment, or growth in reserved shares, is denoted by $N R S_{t}$. That is, $N R S_{t}$ denotes newly authorized reserved shares. All newly authorized reserved shares are voted on by the board of directors, and they should be reported to the SEC at least annually. However, comprehensive data on new share authorizations are not reliably available electronically. The stock of reserved shares also depreciates due to exercised stock options and vested restricted stock (denoted $E X C_{t}$ ) and also due to expired options or retired restricted stock (denoted by EXPt).

In practice, the process of authorizing new reserved shares is lumpy. Similar to a plan for capital expenditures, firms construct a plan for new share issuances (e.g., for compensation, warrants, secondary offerings). When this plan is revised significantly, the firm authorizes a new block of reserved shares, $N R S_{t}$. These newly authorized shares are then used to grant options and restricted stock compensation over the next $g p$ years, where the granting period $g p$ denotes the time between the shares being authorized and being allocated to compensation grants. It should be noted that 
firms also manage their stock of reserved shares, similar to the way firms manage their cash to ensure a sufficient supply to satisfy liquidity needs but no more than this, due to opportunity costs. They are required to reserve enough shares to satisfy compensation grants that are likely to be exercised or vested. On the other hand, firms avoid reserving too many shares because investors know that any new shares from employee compensation will result in the dilution of existing shares. Thus, firms strive to authorize new shares in a way that balances these tradeoffs.

Assume that the average granting period of the initial stock of reserved shares at time $t, R S_{t}$, is $g p_{0}$. This means that, on average, any previously authorized share is expected to remain on the balance sheet in the stock of $R S_{t}$ for $g p_{0}$ years before being granted. We allow for the granting period to differ for any given block of newly authorized shares, $N R S_{t}$, and we denote the average granting period for $N R S_{t}$ by $g p_{t}$. What will be important for determining the fraction of the stock of reserved shares that represents the current flow of employee compensation grants is a weighted average of the granting period for all reserved shares on the balance sheet. For parsimony, we assume that all newly authorized shares are evenly granted over the next $g p_{t}$ periods:

$$
N R S_{t}=\sum_{k=t}^{t+g p_{t}} \text { Annual Grants }(\mathrm{AG})_{k}=g p_{t} \cdot A G_{t} .
$$

For further simplification, we assume that

1) On average, employees exercise a fraction $e$ of the total reserved shares 34

$$
E X C_{t}=e \cdot R S_{t} \forall 0<e<1 \text {. }
$$

2) On average, outstanding restricted stocks or stock options display a constant attrition rate $c$ due to forfeiture, expiration, or

$$
E X P_{t}=c \cdot R S_{t} \forall 0<c<1
$$

Using Equations (22), (23), and (24), we can rewrite the law of motion (21) as

$$
\begin{aligned}
R S_{t+1} & =\left(R S_{t}-E X C_{t}-E X P_{t}\right)+N R S_{t} \\
& =(1-e-c) R S_{t}+g p_{1} \cdot A G_{t} .
\end{aligned}
$$

To correctly capture the annual share-based compensation granted to employees at time $t$ (denoted by $N G_{t}$ ) for "new grants," we must include the following two components:

1. AG: annual grants from newly reserved shares, $N R S_{t}$

2. PG: annual grants from the stock of previously reserved shares, $\frac{R S_{t}}{g p_{0}}$

Note, we can rewrite the law of motion for $R S_{t+1}$ as

$$
R S_{t+1}=\underbrace{\left(g p_{0}-e \cdot g p_{0}-c \cdot g p_{0}\right)}_{\begin{array}{c}
\text { average remaining granting period } \\
\text { after exercising and expiration }
\end{array}} \frac{R S_{t}}{g p_{0}}+g p_{1} \cdot A G_{t} .
$$

\footnotetext{
${ }^{34}$ Employees exercise stock options, or their stock vests, after $e_{0} \cdot g p_{0}$ periods. We assume that one outstanding stock option has the right to purchase one common share of the firm. This is consistent with common practice.
} 
Dividing both sides by $\frac{R S_{t+1}}{\frac{\left(g p_{0}-e \cdot g p_{0}-c \cdot g p_{0}\right) \frac{R S_{t}}{g p_{0}}+v p_{1} \cdot A G_{t}}{A G_{t}+\frac{R S_{t}}{g p_{0}}}}$ and multiplying by $A G_{t}+\frac{R S_{t}}{g p_{0}}$, we obtain

$$
\begin{aligned}
N G_{t}=A G_{t}+\frac{R S_{t}}{g p_{0}} & =\frac{R S_{t+1}}{\frac{\frac{\left(g p_{0}-e \cdot g p_{0}-c \cdot g p_{0}\right) \frac{R S_{t}}{g p_{0}}+g p_{t} \cdot A G_{t}}{A G_{t}+\frac{R S_{t}}{g p_{0}}}}{R S_{t+1}}} \\
& =\frac{\underbrace{(1-e-c) g p_{0} \omega_{0}+g p_{t} \omega_{1}}}{}
\end{aligned}
$$

weighted average granting period

where $\omega_{0}=\frac{\frac{R S_{t}}{g p_{0}}}{A G_{t}+\frac{R S_{t}}{g p_{0}}}$ and $\omega_{1}=\frac{A G_{t}}{A G_{t}+\frac{R S_{t}}{g p_{0}}}$.

Hence, the flow of share-based compensation at period $t$ is $\frac{R S_{t+1}}{\overline{g p}}$, where $\overline{g p}$ denotes the average time that any existing or newly authorized reserved share remains on the balance sheet before being allocated to a compensation grant. Since $e, c \in(0,1)$, the weighted average granting period should be a value between $g p_{0}$ and $g p_{1}$.

To match the theory to the data, we note that this derivation uses $t$ to denote values at the beginning of each period, as is standard in macroeconomic notation. However, since accounting data are recorded at the end of each period, we use the end-of-period data to measure the deferred compensation flow for the annual period ending at the date of the accounting entry. That is, we use a fraction of the stock of reserved shares recorded at the end of year $t$ to measure the flow of new grants during year $t$.

\subsection{Derivation of Equation (16)}

Under the symmetric equilibrium, the returns to physical capital and human capital can be derived from the first-order conditions of the profit maximization problem:

$$
\begin{aligned}
& f_{k}=z \alpha_{c} \alpha_{k}\left(\frac{y}{\Psi}\right)^{1-\sigma}\left(\frac{\Psi}{k}\right)^{1-\rho}=\mu_{t} R^{k}, \\
& f_{h}=z \alpha_{c}\left(1-\alpha_{k}\right)\left(\frac{y}{\Psi}\right)^{1-\sigma}\left(\frac{\Psi}{h}\right)^{1-\rho}=\mu_{t} R^{h}
\end{aligned}
$$

where $\Psi=\left(\alpha_{k} k^{\rho}+\left(1-\alpha_{k}\right) h^{\rho}\right)^{\frac{1}{\rho}}$. From the above equations, the ratio between physical and human capital is a function of the relative return to the two types of capital:

$$
\frac{h}{k}=\left[\frac{\left(1-\alpha_{k}\right) R^{k}}{\alpha_{k} R^{h}}\right]^{\frac{1}{1-\rho}} \equiv \mathbf{B} .
$$

We can derive the total capital share $s_{k}+s_{h}$ as $1-s_{n}$ as

$$
\begin{aligned}
1-s_{n} & =s_{k}+s_{h}=\frac{\left(1-\alpha_{k}\right)\left(\frac{Y}{\Psi}\right)^{1-\sigma} \Psi^{1-\rho}\left[\alpha_{k} k^{\rho}+\left(1-\alpha_{k}\right) h^{\rho}\right]}{\mu Y}+1-\frac{1}{\mu} \\
& =\frac{\alpha_{c}\left(\frac{Y}{\Psi}\right)^{1-\sigma} \Psi^{1-\rho} \Psi^{\rho}}{\mu Y}+1-\frac{1}{\mu}=\frac{\alpha_{c}}{\mu}\left(\frac{Y}{\Psi}\right)^{-\sigma}+1-\frac{1}{\mu} .
\end{aligned}
$$


Find $\frac{Y}{\Psi}$ as a function of prices:

$$
\begin{aligned}
h & =\mathbf{B} k \\
\Psi & =\left[\alpha_{k} k^{\rho}+\left(1-\alpha_{k}\right) \mathbf{B}^{\rho} k^{\rho}\right]^{\frac{1}{\rho}}=\left(\alpha_{k}+\left(1-\alpha_{k}\right) \mathbf{B}^{\rho}\right)^{\frac{1}{\rho}} k \equiv \mathbf{C} k .
\end{aligned}
$$

Since $\Psi$ is linear in $k$, we obtain the expression of capital (non-labor) share in the function of prices as

$$
\begin{aligned}
\frac{Y}{\Psi} & =\frac{Y}{\mathbf{C} k}=\left[\frac{R^{k}}{\alpha_{c} \alpha_{k} \mathbf{C}^{1-\rho}}\right]^{\frac{1}{1-\sigma}} \\
1-s_{n} & =\frac{\alpha_{c}}{\mu}\left[\frac{\alpha_{c} \alpha_{k} \mathbf{C}^{1-\rho}}{R^{k}}\right]^{\frac{\sigma}{1-\sigma}}+1-\frac{1}{\mu} \\
& =\frac{1}{\mu} \alpha_{c}^{\frac{1}{1-\sigma}} \alpha_{k}^{\frac{\sigma}{1-\sigma}} \mathbf{C}^{\frac{\sigma(1-\rho)}{1-\sigma}} R^{\frac{\sigma}{\sigma-1}}+1-\frac{1}{\mu} .
\end{aligned}
$$


Table 2: Descriptive Statistics

Panel A reports descriptive statistics (means, medians, and standard deviations) for our 4-SIC industry-level manufacturing sample between 1960 and 2011. The manufacturing sector corresponds to industries covered in the NBER-CES dataset and for which information on their SG\&A expenditures and/or reserved shares is available in Compustat and RiskMetrics. The dataset includes 133 unique industries at the 4-SIC level. The first section reports statistics for the total human capital share, unskilled labor share, total labor share, and the structure of skilled labor pay, measured by the ratio of equity-based pay to total pay. The second section reports changes in these variables. The third section reports statistics for equity-based pay based on Black-Sholes valuation from the RiskMetrics sample available 1996-2005. Panel B reports the average of major shares of value added and shares of income for the last four decades, during which investment goods prices and the wage share of value added declined steeply. The time period is 1980-2019. See Section 2.1 and Appendix 6.2 for detailed variable definitions.

Panel A: Summary Statistics

\begin{tabular}{|c|c|c|c|}
\hline & $\begin{array}{c}\text { Mean } \\
(1)\end{array}$ & $\begin{array}{l}\text { St.Dev } \\
\quad(2)\end{array}$ & $\begin{array}{l}\text { Median } \\
\quad(3)\end{array}$ \\
\hline \multicolumn{4}{|l|}{ Levels (pct.pt.): } \\
\hline NG/VADD & 2.4 & 14.1 & 0.2 \\
\hline Skilled Wages/VADD & 16.5 & 7.5 & 15.2 \\
\hline (Skilled Wages $+\mathrm{NG}$ )/VADD & 18.5 & 8.7 & 16.9 \\
\hline NG / (Total Wages + NG) & 10.0 & 13.8 & 4.6 \\
\hline SG\&A/VADD & 11.3 & 5.2 & 10.5 \\
\hline Investment/VADD & 6.5 & 4.1 & 5.4 \\
\hline Total Wages/VADD & 39.5 & 12.5 & 40.5 \\
\hline Unskilled Wages/VADD & 23 & 10.1 & 23.1 \\
\hline Investment Good Prices & 96.6 & 21.1 & 98.1 \\
\hline \multicolumn{4}{|l|}{ Annual Changes (pct.pt.): } \\
\hline$\overline{\mathrm{NG} / \mathrm{VADD}}$ & 0.22 & 5.27 & 0 \\
\hline Skilled Wages/VADD & -0.09 & 2.13 & -0.10 \\
\hline (Skilled Wages + NG)/VADD & -0.02 & 3.45 & -0.06 \\
\hline NG/(Total Wages + NG) & 0.44 & 6.35 & 0 \\
\hline SG\&A/VADD & 0.09 & 1.93 & 0.05 \\
\hline Investment/VADD & -0.01 & 2.24 & 0 \\
\hline Total Wages/VADD & -0.45 & 3.71 & -0.43 \\
\hline Unskilled Wages/VADD & -0.36 & 2.21 & -0.30 \\
\hline Investment Good Prices & -0.76 & 2.12 & -0.62 \\
\hline \multicolumn{4}{|l|}{ Additional Measures (1996-2005, pct. pt.) } \\
\hline (Employee Stock Options, Black-Scholes Value)/VADD & 8.0 & 25.5 & 0.8 \\
\hline (Employee Wealth, Black-Scholes Value)/Stock Mkt Value & 9.3 & 21.3 & 4.1 \\
\hline $\begin{array}{r}\text { (Non-Executive Employee Options, Black-Scholes Value)/ } \\
\text { (Employee Stock Options, Black-Scholes Value) }\end{array}$ & 78.1 & 18.4 & 82.7 \\
\hline (Value of Exercised Options)/Stock Mkt Value & 1.0 & 4.8 & 0.4 \\
\hline \multicolumn{4}{|l|}{ N. of Industries $=133$} \\
\hline N. of obs $=6,303$ & & & \\
\hline
\end{tabular}


Panel B: Time Series Stylized Facts

Levels (pct.pt)

1980-1989

1990-1999

2000-2009

2010-2019

Human Capital Wage Share (Skilled Wages/VADD)

Total Human Capital Share

((NG + Skilled Wages)/VADD)

Total Wage Labor Share (Total Wages/VADD)

Total Labor Share ((NG + Total Wages)/VADD)

Equity Share of Value Added (NG/VADD)

Equity-Based Pay of Total Human

Capital Income (NG/(NG+ Skilled Wages)

Skilled Wage Share of Total Wage

Share (Skilled Wages/Total Wages)

Human Capital Share of Total Labor

Share (NG + Skilled Wages/(Total Wages + NG)

\# Skilled Workers/Total Emp

Equity-Based Pay (Billions \$)
$17 \%$

$18 \%$

$38 \%$

$39 \%$

$1 \%$

$4 \%$

$7 \%$

$14 \% \quad 12 \% \quad 11 \%$

$17 \%$

$18 \% \quad 17 \%$

$25 \% \quad 22 \%$

$31 \% \quad 28 \%$

$6 \% \quad 6 \%$

$34 \%$

$3 \%$

$12 \% \quad 10 \%$

$33 \% \quad 36 \%$

$44 \% \quad 46 \% \quad 46 \% \quad 47 \%$

$\begin{array}{llll}46 \% & 51 \% & 56 \% & 58 \%\end{array}$

$\begin{array}{llll}30 \% & 30 \% & 30 \% & \text { NA }\end{array}$

$\begin{array}{lll}4.1 & 29.1 & 79.5\end{array}$

116.1 
Table 3: The Relation Among Factor Shares: Industry-Level Analysis

This table reports industry-level regressions of the human capital share in a given year on the physical capital share at the 4-SIC level of industry aggregation. The specification that is estimated is as follows:

$$
Y_{i, t}=\alpha+\beta X_{i, t-1}+\mu_{i}+\mu_{t}+\epsilon_{i, t} .
$$

All specifications include time (year, $\left.\mu_{t}\right)$ and industry $\left(\mu_{i}\right)$ effects. We report results for three dependent variables: New grants (NG) which are estimated based on the value of reserved shares, and two measures of the human capital share. The main measure is defined as the sum of skilled wages and new grants relative to value added. The second is the expense-based SG\&A share. As for the independent variables, the physical capital share is the ratio of investment to value added. The unskilled labor share refers to production workers' wages relative to value added. To ease interpretation, all variables are expressed in standard deviation units. The interpretation of each reported coefficient is the change in standard deviations of the dependent variable associated with a one standard-deviation change in the explanatory variable. For example, in the third column, a one standard-deviation change in the physical capital share is associated with about $11 \%$ standard deviation change in the human capital share. The time period is 1960-2011. Standard errors are clustered by industry, with ${ }^{* * *}, * *$, and $*$ denoting significance at the $1 \%, 5 \%$, and $10 \%$ levels, respectively. See Section 2.1 and Appendix 6.2 for detailed variable definitions.

\begin{tabular}{|c|c|c|c|c|c|c|}
\hline & \multicolumn{2}{|c|}{$\begin{array}{c}\text { Equity Comp Share= } \\
\text { NG/VADD }\end{array}$} & \multicolumn{2}{|c|}{$\begin{array}{c}\text { Total H Share }= \\
(\text { Skilled Wages }+ \text { NG }) / \text { VADD }\end{array}$} & \multicolumn{2}{|c|}{ SG\&A/VADD } \\
\hline & (1) & (2) & (3) & (4) & (5) & (6) \\
\hline Physical Capital Share & $\begin{array}{l}0.004 \\
(0.11)\end{array}$ & $\begin{array}{l}0.056^{*} \\
(1.72)\end{array}$ & $\begin{array}{c}0.113^{* * *} \\
(5.46)\end{array}$ & $\begin{array}{l}0.094^{* * *} \\
(4.49)\end{array}$ & $\begin{array}{l}0.010 \\
(0.27)\end{array}$ & $\begin{array}{l}0.031 \\
(0.82)\end{array}$ \\
\hline Unskilled Labor Share & & $\begin{array}{c}-0.475^{* * *} \\
(-4.82)\end{array}$ & & $\begin{array}{c}0.171^{* * *} \\
(2.46)\end{array}$ & & $\begin{array}{c}-0.187^{* * *} \\
(-2.21)\end{array}$ \\
\hline Year FE & $\mathrm{Y}$ & $\mathrm{Y}$ & $\mathrm{Y}$ & $\mathrm{Y}$ & Y & Yes \\
\hline Industry FE & $\mathrm{Y}$ & $\mathrm{Y}$ & $\mathrm{Y}$ & Y & $\mathrm{Y}$ & $\mathrm{Y}$ \\
\hline $\mathrm{N}$ & 6,207 & 6,207 & 6,207 & 6,207 & 6,222 & 6,222 \\
\hline $\mathrm{R} 2$ & 0.345 & 0.378 & 0.074 & 0.094 & 0.141 & 0.153 \\
\hline
\end{tabular}




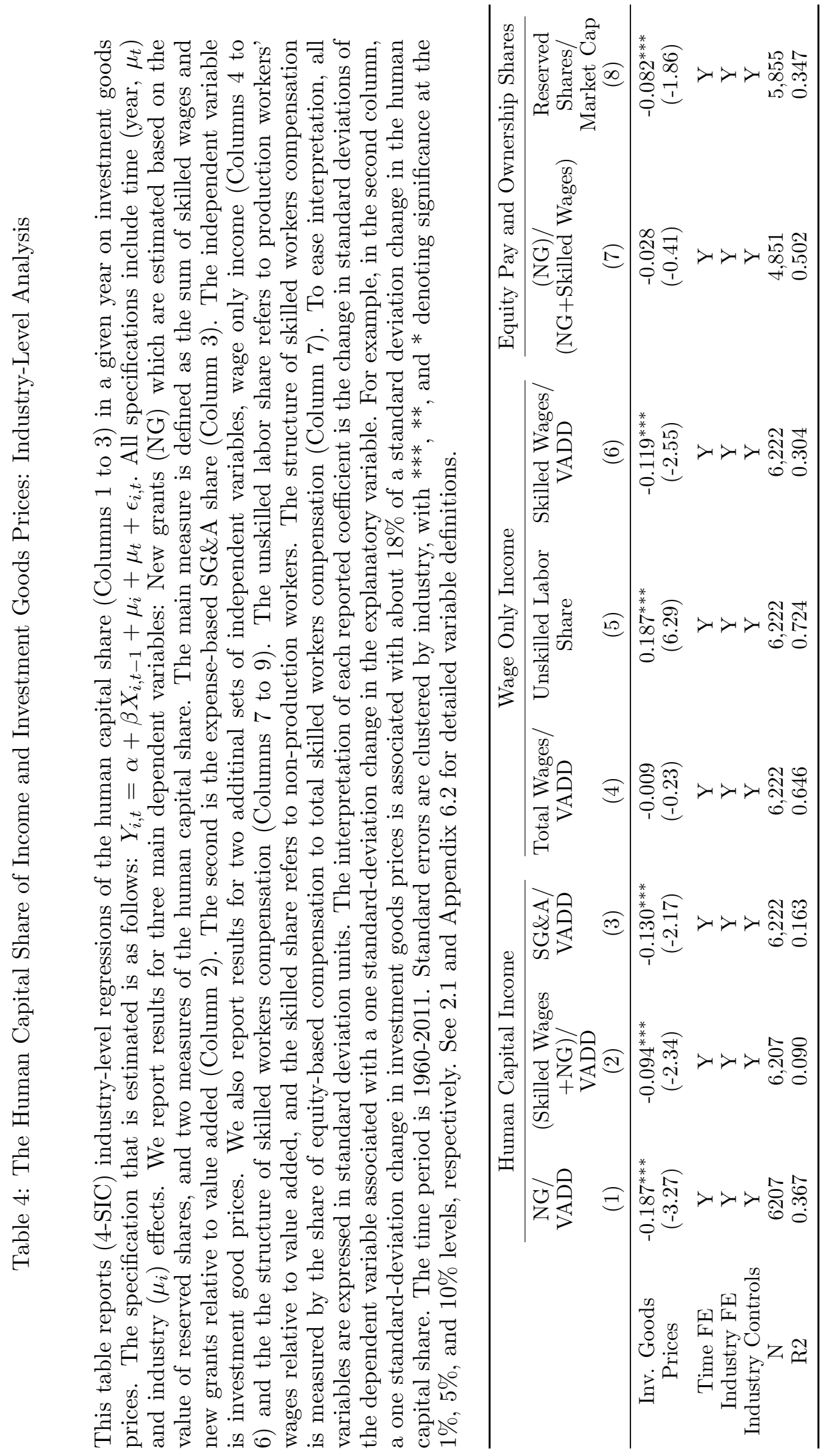


Table 5: The Human Capital Share, Stock Market Value, and Investment Goods Prices: Firm-Level Analysis

This table reports firm-level regressions of the human capital share in a given year on investment goods prices. Column (1 to 2 ) report results for the ownership share (value of reserved shares to market capitalization ratio). Column 3 to 4 report results for the NG to sales ratio. Column 5 to 6 report results for the expense-based measure SG\&A to sales ratio. In Panel A, we report results for a specification with industry fixed effects, which is as follows: $Y_{j, i, t}=\alpha+\beta X_{j, i, t-1}+\mu_{i}+\mu_{t}+\epsilon_{j, i, t}$. All specifications include time (year, $\mu_{t}$ ) and industry $\left(\mu_{i}\right)$ effects. In Panel B, we report results for a specification with firm fixed effects, which is as follows: $Y_{j, i, t}=\alpha+\beta X_{j, i, t-1}+\mu_{j}+\mu_{t}+\epsilon_{j, i, t}$. All specifications include time (year, $\left.\mu_{t}\right)$ and firm $\left(\mu_{j}\right)$ effects. The independent variable is investment good prices. To ease interpretation, all variables are expressed in standard deviation units. The interpretation of each reported coefficient is the change in standard deviations of the dependent variable associated with a one standard-deviation change in the explanatory variable. For example, in Column 1 of Panel A, a one standard-deviation change in investment goods prices is associated with about $9.1 \%$ of a standard deviation change in the ownership share variable. The time period is 1960-2011. Standard errors are clustered by industry in Panel A and by firm in Panel B, with $* * *, * *$, and * denoting significance at the $1 \%, 5 \%$, and $10 \%$ levels, respectively. See Section 2.1 and Appendix 6.2 for detailed variable definitions.

\begin{tabular}{|c|c|c|c|c|c|c|}
\hline \multirow{2}{*}{\multicolumn{3}{|c|}{$\begin{array}{r}\text { Panel A: Industry \& Time Fixed Effects I } \\
\text { Value of Reserved Share } \\
\text { Stock Mkt Value }\end{array}$}} & \multirow{2}{*}{\multicolumn{2}{|c|}{$\begin{array}{l}\text { timates for the Huma } \\
\text { Equity Comp Share } \\
\text { NG/Sales }\end{array}$}} & \multirow{2}{*}{\multicolumn{2}{|c|}{$\begin{array}{c}\text { Capital Share } \\
\text { SG\&A/Sales }\end{array}$}} \\
\hline & & & & & & \\
\hline \multirow[b]{2}{*}{ Inv. Goods Prices } & (1) & $(2)$ & (3) & (4) & (5) & (6) \\
\hline & $\begin{array}{c}-0.091^{* * *} \\
(-4.75)\end{array}$ & $\begin{array}{c}-0.102^{* * *} \\
(-4.74)\end{array}$ & $\begin{array}{c}-0.032^{* *} \\
(-2.52)\end{array}$ & $\begin{array}{l}-0.026 \\
(-1.52)\end{array}$ & $\begin{array}{c}-0.042^{* *} \\
(-2.02)\end{array}$ & $\begin{array}{c}-0.052^{*} \\
(-1.95)\end{array}$ \\
\hline Industry FE & $\mathrm{Y}$ & $\mathrm{Y}$ & $\mathrm{Y}$ & $\mathrm{Y}$ & $\mathrm{Y}$ & Y \\
\hline Firm FE & $\mathrm{N}$ & $\mathrm{N}$ & $\mathrm{N}$ & $\mathrm{N}$ & $\mathrm{N}$ & $\mathrm{N}$ \\
\hline Year FE & $\mathrm{Y}$ & Y & $\mathrm{Y}$ & $\mathrm{Y}$ & Y & Y \\
\hline Firm Controls & $\mathrm{Y}$ & $\mathrm{Y}$ & $\mathrm{Y}$ & $\mathrm{Y}$ & $\mathrm{Y}$ & Y \\
\hline Industry Controls & $\mathrm{N}$ & $\mathrm{Y}$ & $\mathrm{N}$ & $\mathrm{Y}$ & $\mathrm{N}$ & $\mathrm{Y}$ \\
\hline $\mathrm{N}$ & 73,027 & 50,629 & 73,027 & 50,629 & 69,308 & 47,654 \\
\hline \multirow[t]{4}{*}{$\mathrm{R} 2$} & 0.321 & 0.331 & 0.707 & 0.714 & 0.624 & 0.668 \\
\hline & a \& Time I & d Effects Es & mates for & Human & apital Sh & \\
\hline & $\begin{array}{r}\text { Value of } \mathrm{R} \\
\text { Stock }\end{array}$ & $\begin{array}{l}\text { rved Share/ } \\
\text { t Value }\end{array}$ & $\begin{array}{r}\text { Equity C } \\
\mathrm{NG}\end{array}$ & $\begin{array}{l}\text { ip Share } \\
\text { ales }\end{array}$ & SG\& & Sales \\
\hline & (1) & $(2)$ & (3) & (4) & (5) & (6) \\
\hline Inv. Goods Prices & $\begin{array}{c}-0.071^{* * *} \\
(-3.78)\end{array}$ & $\begin{array}{c}-0.076^{* * *} \\
(-3.68)\end{array}$ & $\begin{array}{l}-0.009 \\
(-1.09)\end{array}$ & $\begin{array}{l}-0.012 \\
(-1.13)\end{array}$ & $\begin{array}{c}-0.022^{*} \\
(-1.79)\end{array}$ & $\begin{array}{c}-0.042^{* *} \\
(-2.90)\end{array}$ \\
\hline Industry FE & $\mathrm{N}$ & $\mathrm{N}$ & $\mathrm{N}$ & $\mathrm{N}$ & $\mathrm{N}$ & $\mathrm{N}$ \\
\hline Firm FE & $\mathrm{Y}$ & $\mathrm{Y}$ & $\mathrm{Y}$ & $\mathrm{Y}$ & $\mathrm{Y}$ & Y \\
\hline Year FE & $\mathrm{Y}$ & $\mathrm{Y}$ & $\mathrm{Y}$ & $\mathrm{Y}$ & Y & Y \\
\hline Firm Controls & $\mathrm{Y}$ & $\mathrm{Y}$ & $\mathrm{Y}$ & $Y$ & $\mathrm{Y}$ & Y \\
\hline Industry Controls & $\mathrm{N}$ & $\mathrm{Y}$ & $\mathrm{N}$ & $\mathrm{Y}$ & $\mathrm{N}$ & $\mathrm{Y}$ \\
\hline $\mathrm{N}$ & 72,476 & 50,208 & 72,476 & 50,208 & 68,765 & 47,237 \\
\hline $\mathrm{R} 2$ & 0.625 & 0.633 & 0.830 & 0.834 & 0.899 & 0.907 \\
\hline
\end{tabular}


Table 6: The Relative Growth of the Physical Capital and The Human Capital Share and Investment Goods Prices

This table reports results of additional industry-level regressions of the human capital share in a given year on investment goods prices. The specification that is estimated is as follows: $Y_{i, t}=$ $\alpha+\beta X_{i, t-1}+\mu_{i}+\mu_{t}+\epsilon_{i, t}$. All specifications include time (year, $\left.\mu_{t}\right)$ and industry $\left(\mu_{i}\right)$ effects. New grants (NG) are estimated based on the value of reserved shares. We report results for two measures of the human capital share. The main measure is defined as the sum of skilled wages and new grants relative to value added. The second measure is the expense-based SG\&A share. For each measure, we report results relative to the physical capital share. The independent variable is investment good prices. To ease interpretation, all variables are expressed in standard deviation units. The interpretation of each reported coefficient is the change in standard deviations of the dependent variable associated with a one standard-deviation change in the explanatory variable. For example, in Column 1, a one standard-deviation change in investment goods prices is associated with about $6.4 \%$ of a standard deviation change in the NG share relative to the physical capital share. The time period is 1960-2011. Standard errors are clustered by industry, with ***, **, and * denoting significance at the 1\%,5\%, and 10\% levels, respectively. See 2.1 and Appendix 6.2 for detailed variable definitions.

\begin{tabular}{|c|c|c|c|c|c|c|}
\hline & \multicolumn{2}{|c|}{$\begin{array}{c}\ln (\mathrm{NG} / \mathrm{VADD}) \\
-\ln (\text { Investment/VADD })\end{array}$} & \multicolumn{2}{|c|}{$\begin{array}{c}\ln ((\text { Skilled Wages + NG)/VADD }) \\
-\ln (\text { Investment/VADD })\end{array}$} & \multicolumn{2}{|c|}{$\begin{array}{c}\ln (\mathrm{SG} \& \mathrm{~A} / \mathrm{VADD} \\
-\ln (\text { Investment/VADD })\end{array}$} \\
\hline & $\begin{array}{c}(1) \\
1960-1980\end{array}$ & $\begin{array}{c}(2) \\
1980-2011\end{array}$ & $\begin{array}{c}(3) \\
1960-1980\end{array}$ & $\begin{array}{c}(4) \\
1980-2011\end{array}$ & $\begin{array}{c}(5) \\
1960-1980\end{array}$ & $\begin{array}{c}(6) \\
1980-2011\end{array}$ \\
\hline Inv. Goods Prices & $\begin{array}{c}0.381^{* * *} \\
(4.76)\end{array}$ & $\begin{array}{c}-0.171^{* *} \\
(-2.36)\end{array}$ & $\begin{array}{c}0.169^{* * *} \\
(3.53)\end{array}$ & $\begin{array}{c}-0.131^{* *} \\
(-2.32)\end{array}$ & $\begin{array}{l}-0.012 \\
(-0.15)\end{array}$ & $\begin{array}{c}-0.201^{* *} \\
(-2.54)\end{array}$ \\
\hline Year FE & $\mathrm{Y}$ & $\mathrm{Y}$ & $\mathrm{Y}$ & Y & Y & Y \\
\hline Industry FE & Y & $\mathrm{Y}$ & $\mathrm{Y}$ & Y & $\mathrm{Y}$ & Y \\
\hline Industry Controls & $\mathrm{Y}$ & $\mathrm{Y}$ & $\mathrm{Y}$ & $\mathrm{Y}$ & $\mathrm{Y}$ & $\mathrm{Y}$ \\
\hline $\mathrm{N}$ & 2,327 & 3,880 & 2,327 & 3,880 & 2,306 & 3,875 \\
\hline R2 & 0.116 & 0.242 & 0.203 & 0.206 & 0.204 & 0.168 \\
\hline
\end{tabular}


Table 7: Human Capital Earnings, Factor Share, and Investment Goods Prices: Firm-Level Analysis

This table reports industry- and firm-level regressions of an alternative measure of the new grants share based the Black-Scholes value of new grants of stock options for all employees (Panel A), and excluding the top executives (Panel B) in a given year on investment goods prices, in turn. In Columns 1 to 2, we report results of industry-level analysis for a specification with industry fixed effects, which is as follows: $Y_{i, t}=\alpha+\beta X_{i, t-1}+\mu_{i}+\mu_{t}+\epsilon_{i, t}$. All specifications include time (year, $\mu_{t}$ ) and industry $\left(\mu_{i}\right)$ effects. In Columns 3 to 4 , we report results of firm-level analysis for a specification with firm fixed effects, which is as follows: $Y_{j, i, t}=\alpha+\beta X_{j, i, t-1}+\mu_{j}+\mu_{t}+\epsilon_{j, i, t}$. All specifications include time (year, $\left.\mu_{t}\right)$ and firm $\left(\mu_{j}\right)$ effects. The Black-Scholes value of new grants is relative to value added at the industry level and sales at the firm level. The independent variable is investment good prices. To ease interpretation, all variables are expressed in standard deviation units. The interpretation of each reported coefficient is the change in standard deviations of the dependent variable associated with a one standard-deviation change in the explanatory variable. For example, in the second column of Panel A, a one standard-deviation change in investment goods prices is associated with about $16.8 \%$ of a standard deviation change in the new grants share. The time period is 1996-2005. Standard errors are clustered by industry in the industry-level analysis and by firm in the firm-level analysis, with $* * *, * *$, and $*$ denoting significance at the $1 \%, 5 \%$, and $10 \%$ levels, respectively. See Section 2.1 and Appendix 6.2 for detailed variable definitions.

\begin{tabular}{|c|c|c|c|c|}
\hline \multirow[b]{3}{*}{ Investment Goods Prices } & \multicolumn{4}{|c|}{$\begin{array}{c}(\text { Employee Stock Options, Black-Scholes Value)/ } \\
\text { VADD }\end{array}$} \\
\hline & \multicolumn{2}{|c|}{$\begin{array}{l}(1) \quad(2) \\
\text { Industry-level }\end{array}$} & \multicolumn{2}{|c|}{${ }_{\text {Firm-level }}^{(4)}$} \\
\hline & $\begin{array}{c}-0.210^{* * *} \\
(0.067)\end{array}$ & $\begin{array}{c}-0.168^{* *} \\
(0.091)\end{array}$ & $\begin{array}{c}-0.848^{* * *} \\
(0.231)\end{array}$ & $\begin{array}{c}-0.665^{* * *} \\
(0.230)\end{array}$ \\
\hline $\begin{array}{l}\text { Time Effects } \\
\text { Industry Effects } \\
\text { Firm Effects } \\
\text { Firm Controls }\end{array}$ & $\begin{array}{l}\text { Yes } \\
\text { No } \\
\text { No } \\
\text { No }\end{array}$ & $\begin{array}{l}\text { Yes } \\
\text { Yes } \\
\text { No } \\
\text { No }\end{array}$ & $\begin{array}{l}\text { Yes } \\
\text { No } \\
\text { Yes } \\
\text { No }\end{array}$ & $\begin{array}{l}\text { Yes } \\
\text { No } \\
\text { Yes } \\
\text { Yes }\end{array}$ \\
\hline $\begin{array}{l}\text { N. of obs. } \\
\mathrm{R}^{2}(\%)\end{array}$ & $\begin{array}{c}1,282 \\
8.99 \\
\end{array}$ & $\begin{array}{l}1,282 \\
51.51 \\
\end{array}$ & $\begin{array}{l}3,357 \\
80.62 \\
\end{array}$ & $\begin{array}{l}3,314 \\
81.44 \\
\end{array}$ \\
\hline & \multicolumn{4}{|c|}{$\frac{(\text { Non-Exec Employee Stock Options, B-S Value) } /}{\text { VADD }}$} \\
\hline & \multicolumn{2}{|c|}{$\begin{array}{l}(1) \\
\text { Industry-level }\end{array}$} & \multicolumn{2}{|c|}{ Firm-level } \\
\hline Investment Goods Prices & $\begin{array}{c}-0.205^{* * *} \\
(0.067)\end{array}$ & $\begin{array}{c}-0.171^{* *} \\
(0.090)\end{array}$ & $\begin{array}{c}-0.841^{* * *} \\
(0.265)\end{array}$ & $\begin{array}{c}-0.677^{* *} \\
(0.267)\end{array}$ \\
\hline $\begin{array}{l}\text { Time Effects } \\
\text { Industry Effects } \\
\text { Firm Effects } \\
\text { Firm Controls }\end{array}$ & $\begin{array}{l}\text { Yes } \\
\text { No } \\
\text { No } \\
\text { No }\end{array}$ & $\begin{array}{l}\text { Yes } \\
\text { Yes } \\
\text { No } \\
\text { No }\end{array}$ & $\begin{array}{l}\text { Yes } \\
\text { No } \\
\text { Yes } \\
\text { No }\end{array}$ & $\begin{array}{l}\text { Yes } \\
\text { No } \\
\text { Yes } \\
\text { Yes }\end{array}$ \\
\hline $\begin{array}{l}\text { N. of obs. } \\
\mathrm{R}^{2}(\%)\end{array}$ & $\begin{array}{l}1,282 \\
8.97\end{array}$ & $\begin{array}{l}1,282 \\
51.20\end{array}$ & $\begin{array}{l}3,017 \\
80.73\end{array}$ & $\begin{array}{l}2,982 \\
81.10\end{array}$ \\
\hline
\end{tabular}




\section{Internet Appendix:}

Supplementary Materials: Not for Print Publication

\section{Sample Comparison}

Our merged NBER-CES-public-firm sample presents a high degree of similarity to the overall NBER-CES universe. Figure IA1 shows the time series of labor shares in both the NBER-CES sample and in the merged NBER-CES-public-firm sample. Without including equity-based compensation, these two samples show similar levels and trends in all three labor share measures.

Figure IA1: Factor Shares Across Different Samples

The top panel shows the total labor share, unskilled labor share, and skilled labor share (without equity-based compensation) in the NBER-CES sample and the merged NBER-CES-public-firm sample. The sample is from 19602011.
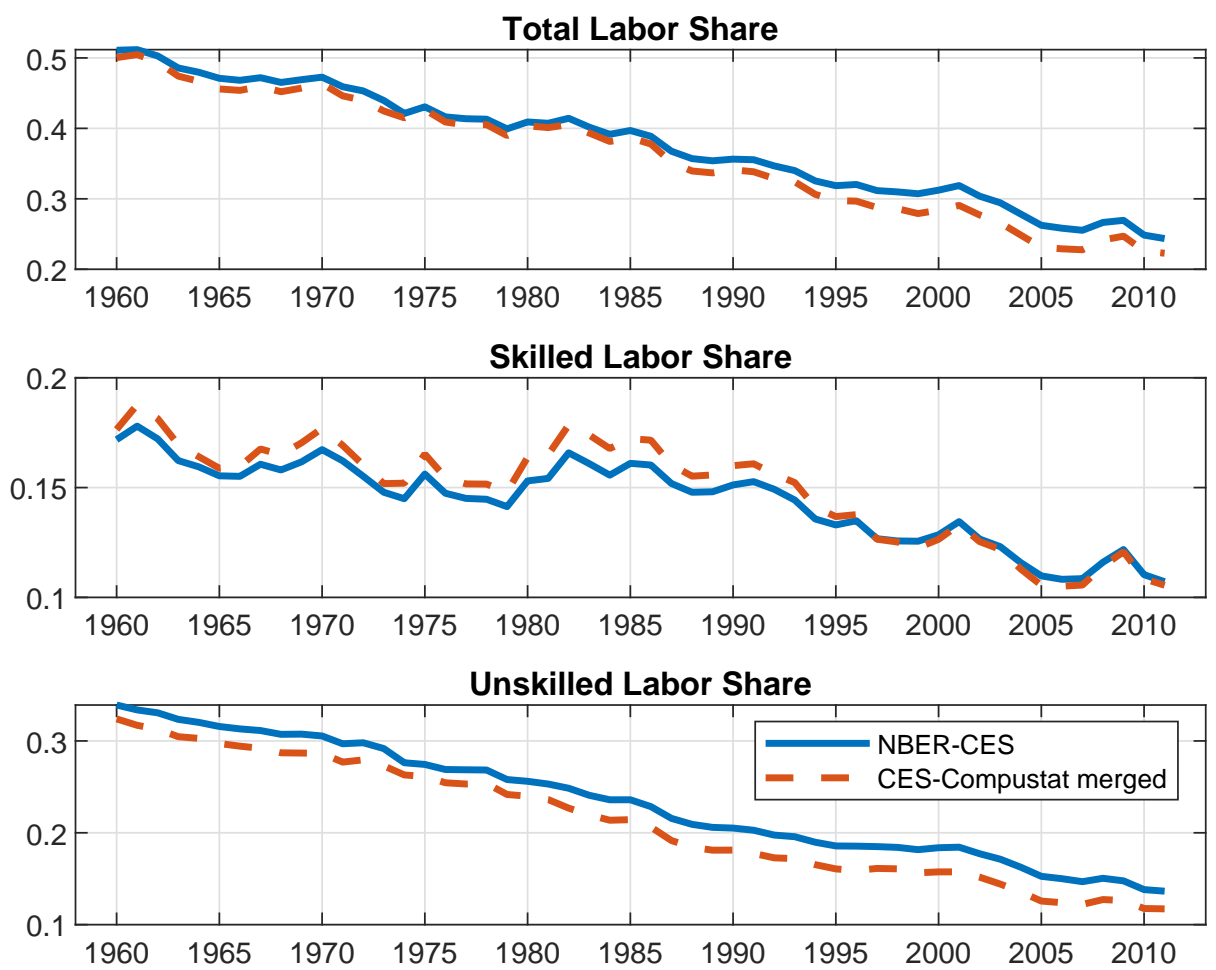

\section{Human Capitalist Income: Equity Pay, Robustness Checks}

We present several robustness checks to our main measure of the annual flow of equity-based compensation, $N G=\frac{R S}{g p}$, in Figure IA2, The top panel of Figure IA2 shows that using firms' actual granting periods from 1996 to 2005 from Risk Metrics data yields very similar dynamics to our measure using a constant six year weighted-average granting period 35

\footnotetext{
${ }^{35}$ for the shorter time period, we also have information on whether a firm discloses all available reserved shares in its $10-\mathrm{K}$ filing. This is the case for $80 \%$ of the firms, further supporting the accuracy of our estimate for $N G$.
} 
Next, we construct a measure of new grants to value added using the aggregate Black and Scholes (1973) value of newly granted stock options (BS) from Risk Metrics for the period 19962005. The middle panel of Figure IA2 plots the aggregated BS value relative to value added, along with our baseline measure including shares reserved for both options and restricted stock grants. As is apparent in the Figure, these two measures are highly correlated for the shorter sample when both are available. The time series correlation between the ratio of BS to value added and the ratio of $N G$ to value added is $0.52{ }^{36}$ There are a few reasons why the BS share of value added is somewhat lower than our reserved-share measure. The main reason is that there is substantial evidence (see, for example, Aboody, Barth, and Kasznik (2006)) that once firms were required to expense option grants, they began to significantly understate their value. Another reason that the BS share is lower is that it does not include restricted stock grants, which became increasingly popular relative to options after the severe downturns in equity valuations in 2000 and 2008. Indeed, Bachelder (2014) estimates that in recent years about half of equity-based compensation is in the form of restricted stock.

The bottom left panel of Figure IA2 plots the aggregate human capital income share based on a fraction of the Selling, General, and Administrative (SG\&A) expense that includes all wages and equity compensation allocated to headquarters, as discussed in the main text.

\section{Figure IA2: Measures of Equity-Based Compensation as a Fraction of Value Added}

This plot reports the time series of our three grant-based measures and one expense-based measure of the aggregate equity-based ratio of compensation to value added. In the top left panel, the solid blue line NG/Vadd reports the annual flow of equity-based compensation using $\mathrm{NG}=\mathrm{RS} / 7$, where 7 is the weighted average granting period. The the dotted red line NG(Actual GP) is the aggregate value of reserved shares divided by the actual average remaining life of RS on the balance sheets in the IRRC sample. In the top right panel, the dashed pink line BS/Vadd is the aggregate Black-Scholes value of newly granted stock options relative to value added constructed using the IRRC sample from 1996-2005. The solid blue line is NG=RS/7. In the bottom right panel, the annual flow of equity-based compensation is the expense-based measure 0.3SG\&A. Data source: Compustat Fundamental Annual (1960-1996), RiskMetrics (IRRC) (1996-2005), and NBER-CES Manufacturing Industry Database (1960-2005). The sample period is from 1960 to 2005.
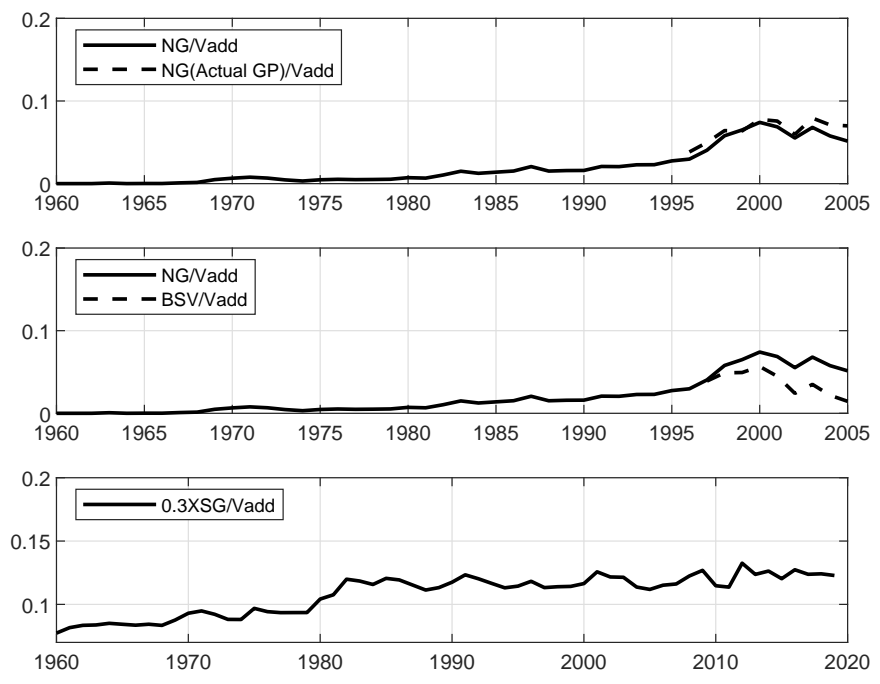

\footnotetext{
${ }^{36}$ In pooled time series cross section data using 4-digit SIC industry-level observations, we find that the correlation between the ratio of $\mathrm{BS}$ to value added and the ratio of $N G$ to value added is 0.97 .
} 
Table IA1: The Human Capital Share and Investment Goods Prices: Additional Industry-Level Analysis

This table reports (4-SIC) industry-level regressions of alternative measures of the human capital share in a given year on investment good prices. We report results for three alternative estimates of the value of equity pay from stock options. All defined relative to value added. The first measure is based on the value of diluted earnings per share (Column 2). The intuition for this measure is that dilution reflects expected equity issuance from actual and/or expected exercise of options grants. The number of shares from dilution is measured as the difference between common shares used to calculate diluted earnings per share and common shares used to calculate basic earnings per share. The value of dilution is equal to the product between the number of shares from dilution and the stock price. The second measure is based on the value of stock repurchases (Column 3). The intuition for this alternative measure is that firms repurchase stock to offset dilution from actual and/or expected exercise of options grants. The third measure is based on the value of small stock issuance (Column 4). Small stock issues are defined as those whose value is smaller than three percent of total assets. The intuition for this alternative measure is that small stock issuance is predominantly related to actual and/or expected exercise of option grants, while large issues are predominantly motivated by financing needs (McKeon, 2013). To ease interpretation, all variables are expressed in standard deviation units. The interpretation of each reported coefficient is the change in standard deviations of the dependent variable associated with a one standard-deviation change in the explanatory variable. For example, in the first column, a one standard-deviation change in investment good prices is associated with about $13 \%$ of a standard deviation change in the baseline NG share. The time period is 1960-2011. All specifications include time (year) and industry effects. Standard errors are robust, with ***,**, and * denoting significance at the $1 \%, 5 \%$, and $10 \%$ levels, respectively. See Section 2.2 and Appendix 6.2 for detailed variable definitions.

\begin{tabular}{lcccc}
\hline & Baseline NG/VADD & $\begin{array}{c}\text { Diluted EPS } \\
(1)\end{array}$ & $\begin{array}{c}\text { Repurchases } \\
(2)\end{array}$ & $\begin{array}{c}\text { Small Issues } \\
(4)\end{array}$ \\
\hline Inv. Goods Prices & $-0.187^{* * *}$ & $-0.146^{* * *}$ & $-0.051^{* * *}$ & $-0.179^{* * *}$ \\
& $(-12.20)$ & $(-7.62)$ & $(-2.68)$ & $(-9.92)$ \\
Year FE & $\mathrm{Y}$ & $\mathrm{Y}$ & $\mathrm{Y}$ & $\mathrm{Y}$ \\
Industry FE & $\mathrm{Y}$ & $\mathrm{Y}$ & $\mathrm{Y}$ & $\mathrm{Y}$ \\
Industry Controls & $\mathrm{Y}$ & $\mathrm{Y}$ & $\mathrm{Y}$ & $\mathrm{Y}$ \\
$\mathrm{N}$ & 6,207 & 6,207 & 6,207 & 6,207 \\
$\mathrm{R} 2$ & 0.531 & 0.263 & 0.272 & 0.349 \\
\hline Mean LHS (pct. pt.) & & & & \\
All & 2.4 & 5.2 & 4.6 & 1.5 \\
\hline
\end{tabular}

\section{Diluted EPS and Share Repurchases}

In Tables IA1 and IA2, we confirm that the relation is robust to two important sensitivity checks: First, Table IA1 shows that the relation is robust to using a battery of alternative approaches to measuring the human capitalists' income share, which are based on firm estimates of diluted earnings from option exercise or based on the value of stock repurchases to offset expected dilution from option exercise or small issues of new stock primarily related to option exercise (see table legend for detailed definitions of these alternative measures). Second, Appendix Table IA2 shows that the relation is robust to expanding the sample to the public-firm universe by also including the non-manufacturing sectors.

\section{Additional Cross Section Evidence}

This section reports additional cross-sectional facts about equity-based compensation. 
Table IA2: The Human Capital Share, Stock Market Value, and Investment Goods Prices: Additional Firm-Level Analysis

This table reports firm-level regressions of the human capital share in a given year on investment goods prices for an expanded sample that includes non-manufacturing industries. Specifically, we add to the core manufacturing industries from NBER-CES (SIC 2000-3999) information on investment good prices from Cummins and Violante (2002) for the following non-manufacturing industries: Agriculture, Forestry, \& Fishing (SIC 0100-0999), Mining \& Construction (SIC 1000-1999), Transportation (SIC 4000-4999), Wholesale \& Retail Trade (SIC 5000-5999), Finance (SIC 6000-6999), and Services (SIC 7000-8999). We report results for the ownership share (Columns 1 to 2), which is defined relative to stock market value, the results for NG/Sales ratio (Columns 3 to 4) and the results for SG\&A to sales ratio (Column 5 to 6). To ease interpretation, all variables are expressed in standard deviation units. The interpretation of each reported coefficient is the change in standard deviations of the dependent variable associated with a one standard-deviation change in the explanatory variable. The time period is 1960-2011. All specifications include time (year) effects. Standard errors are robust, with $* * *, * *$, and $*$ denoting significance at the $1 \%, 5 \%$, and $10 \%$ levels, respectively. See Section 2.2 and Appendix 6.2 for detailed variable definitions.

\begin{tabular}{|c|c|c|c|c|}
\hline & \multicolumn{2}{|c|}{$\begin{array}{c}\text { Equity Comp Share } \\
\text { NG/Sales }\end{array}$} & \multicolumn{2}{|c|}{ SG\&A/Sales } \\
\hline & (1) & $(2)$ & $(3)$ & $(4)$ \\
\hline Inv. Goods Prices & $\begin{array}{c}-0.020^{* * *} \\
(-4.44)\end{array}$ & $\begin{array}{c}-0.025^{* * *} \\
(-4.86)\end{array}$ & $\begin{array}{c}-0.031^{* * *} \\
(-5.31)\end{array}$ & $\begin{array}{c}-0.031^{* * *} \\
(-6.45)\end{array}$ \\
\hline Firm FE & $\mathrm{N}$ & $\mathrm{Y}$ & $\mathrm{N}$ & $\mathrm{Y}$ \\
\hline Industry FE & $\mathrm{Y}$ & $\mathrm{N}$ & $\mathrm{Y}$ & $\mathrm{N}$ \\
\hline Firm Controls & $\mathrm{Y}$ & $\mathrm{Y}$ & $\mathrm{Y}$ & $\mathrm{Y}$ \\
\hline $\mathrm{N}$ & 110,688 & 109,611 & 98,130 & 97,140 \\
\hline $\mathrm{R} 2$ & 0.636 & 0.771 & 0.578 & 0.877 \\
\hline
\end{tabular}

\section{IV.1 Industry}

Figure IA3 plots the equity-based compensation share of value added by industry. Clearly, there is substantial heterogeneity across industries, with the high-tech and health sectors represented within the NBER-CES manufacturing database showing the largest increase.

\section{IV.2 Firm Size}

We define the equity-based compensation share as the ratio of $N G$ to sales at the firm level. We analyze the cross sections of equity-based compensation as a share of total output.

First, equity-based compensation is not just a phenomenon of a subsample of large firms. Instead, we find that equity-based compensation is more concentrated among small firms in the sample. In Figure IA4, We categorize firms into five quantiles based on their total assets, and we plot the NG-to-sales ratio within each group over the sample period from 1970-1995. As a fraction of output (measured by sales), small firms (solid blue line) offer $10 \%$ more equity-based compensation to employees than the largest quantile (yellow line). As a result, the average NG-adjusted total labor income share should be higher than the aggregate trend, since smaller firms are overweighted when calculating the average. In fact, the increase in equity-based compensation among smaller firms enhances the divergence of the average and the aggregate total labor share (see Figure IA5) found by Hartman-Glaser et al. (2019).

\section{IV.3 Human Capital Wealth}

We examine the relation between a measure of human capitalists' wealth and investment goods prices across industries and firms. Table IA3 repeats our main cross section analysis using the 
Figure IA3: Equity-Based Compensation Share of Value Added: Industry

The plot report the aggregate equity-based compensation (NG) share of value added in the four sub-industries: Consumer Goods, Manufacturing, High Tech and Health Products. Data source: Compustat Fundamental Annual (1960-1996), RiskMetrics (IRRC) (1996-2005), and NBER-CES Manufacturing Industry Database (1960-2011). The sample period is from 1960 to 2011.

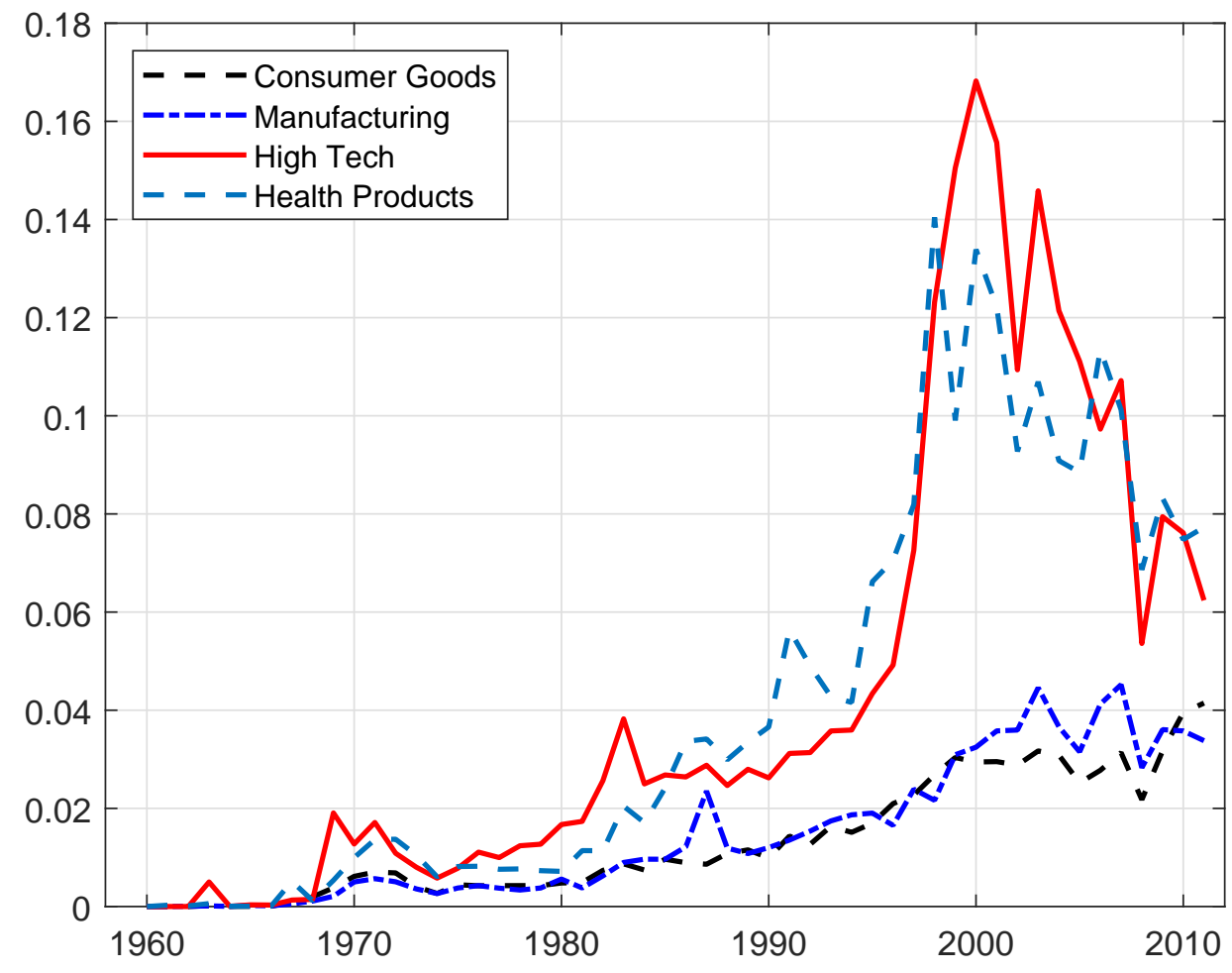

(Black-Scholes) value of employees' current and past stock option grants relative to stock market capitalization. This measure is broader than the income measure because it captures not only new grants but also the capital appreciation of past grants. Thus, it is a proxy for the stock of equity compensation human capitalists receive, or, equivalently, human capitalists' compensation wealth. The negative relation with investment goods prices controlling for industry or firm fixed effects is even stronger for this more comprehensive measure, which offers additional reassurance that our baseline estimates indeed reflect an economically important relation between investment goods prices and human capitalists' income. 


\section{Table IA3: Human Capital Wealth and Investment Goods Prices: Firm-Level Analysis}

This table reports industry- and firm-level regressions of an alternative measure of the human capital ownership share based on the Black-Scholes value of past unexpired grant, and new grants of stock options for all employees (Panel A), and excluding top executives (Panel B) in a given year on investment goods prices, in turn. To ease interpretation, all variables are expressed in standard deviation units. The interpretation of each reported coefficient is the change in standard deviations of the dependent variable associated with a one standard-deviation change in the explanatory variable. For example, in the first column of Panel A, a one standard-deviation change in investment goods prices is associated with about $10 \%$ of a standard deviation change in the human capital ownership share. The time period is 1996-2005. All specifications include time (year) and either industry or firm effects. Standard errors are robust, with $* * *, * *$, and $*$ denoting significance at the $1 \%, 5 \%$, and $10 \%$ levels, respectively. See Section 2.2 and Appendix 6.2 for detailed variable definitions.

\begin{tabular}{|c|c|c|c|c|}
\hline \multirow[b]{3}{*}{ Investment Goods Prices } & \multicolumn{4}{|c|}{$\begin{array}{c}\text { (Employee Wealth, Black-Scholes Value)/ } \\
\text { Stock Mkt Value }\end{array}$} \\
\hline & \multicolumn{2}{|c|}{$\begin{array}{l}(1) \\
\text { Industry-level }\end{array}$} & Firm-level & vel $(4)$ \\
\hline & $\begin{array}{c}-0.163^{* * *} \\
(0.026)\end{array}$ & $\begin{array}{c}-0.366^{* * *} \\
(0.128)\end{array}$ & $\begin{array}{c}-0.362^{* *} \\
(0.166)\end{array}$ & $\begin{array}{c}-0.370^{* *} \\
(0.176)\end{array}$ \\
\hline $\begin{array}{l}\text { Time Effects } \\
\text { Industry Effects } \\
\text { Firm Effects } \\
\text { Firm Controls }\end{array}$ & $\begin{array}{l}\text { Yes } \\
\text { No } \\
\text { No } \\
\text { No }\end{array}$ & $\begin{array}{l}\text { Yes } \\
\text { Yes } \\
\text { No } \\
\text { No }\end{array}$ & $\begin{array}{l}\text { Yes } \\
\text { No } \\
\text { Yes } \\
\text { No }\end{array}$ & $\begin{array}{l}\text { Yes } \\
\text { No } \\
\text { Yes } \\
\text { Yes }\end{array}$ \\
\hline \multirow[t]{2}{*}{$\begin{array}{l}\text { N. of obs. } \\
\mathrm{R}^{2}(\%)\end{array}$} & $\begin{array}{l}1,111 \\
25.09\end{array}$ & $\begin{array}{l}1,111 \\
35.17\end{array}$ & $\begin{array}{l}2,506 \\
75.83\end{array}$ & $\begin{array}{l}2,714 \\
77.33\end{array}$ \\
\hline & $\begin{array}{l}(1) \\
\text { Industry-level }\end{array}$ & $\begin{array}{c}\text { (Non-Exec Employee Wealth, B-S Value)/ } \\
\text { Stock Mkt Value }\end{array}$ & \begin{tabular}{l} 
Jealth, B-S \\
Value \\
\multicolumn{1}{c}{$(3){ }_{\text {Fir }}$}
\end{tabular} & $\frac{\text { vel }^{(4)} /}{(4)}$ \\
\hline Investment Goods Prices & $\begin{array}{c}-0.394^{* * *} \\
(0.034)\end{array}$ & $\begin{array}{c}-0.290^{* *} \\
(0.096)\end{array}$ & $\begin{array}{c}-0.568^{* * *} \\
(0.209)\end{array}$ & $\begin{array}{c}-0.510^{* *} \\
(0.223)\end{array}$ \\
\hline $\begin{array}{l}\text { Time Effects } \\
\text { Industry Effects } \\
\text { Firm Effects } \\
\text { Firm Controls }\end{array}$ & $\begin{array}{l}\text { Yes } \\
\text { No } \\
\text { No } \\
\text { No }\end{array}$ & $\begin{array}{l}\text { Yes } \\
\text { Yes } \\
\text { No } \\
\text { No }\end{array}$ & $\begin{array}{l}\text { Yes } \\
\text { No } \\
\text { Yes } \\
\text { No }\end{array}$ & $\begin{array}{l}\text { Yes } \\
\text { No } \\
\text { Yes } \\
\text { Yes }\end{array}$ \\
\hline $\begin{array}{l}\text { N. of obs. } \\
\mathrm{R}^{2}(\%)\end{array}$ & $\begin{array}{l}1,111 \\
13.77\end{array}$ & $\begin{array}{l}1,111 \\
59.50\end{array}$ & $\begin{array}{l}2,071 \\
78.22\end{array}$ & $\begin{array}{l}2,218 \\
78.62\end{array}$ \\
\hline
\end{tabular}


Figure IA4: Equity-based compensation as share of sales

This figure shows the equity-based compensation NG-to-sales ratios across size groups. Size is measured as total assets. Firms are categorized into five quantiles based on total assets, and the NG-to-sales ratio is $\frac{\sum_{i} N G_{i}}{\sum_{i} \text { Sales }_{i}}$ ratio within each group. The sample is winsorized at 1\%. The sample is from 1970-1995, from the Compustat-CRSP merged database.

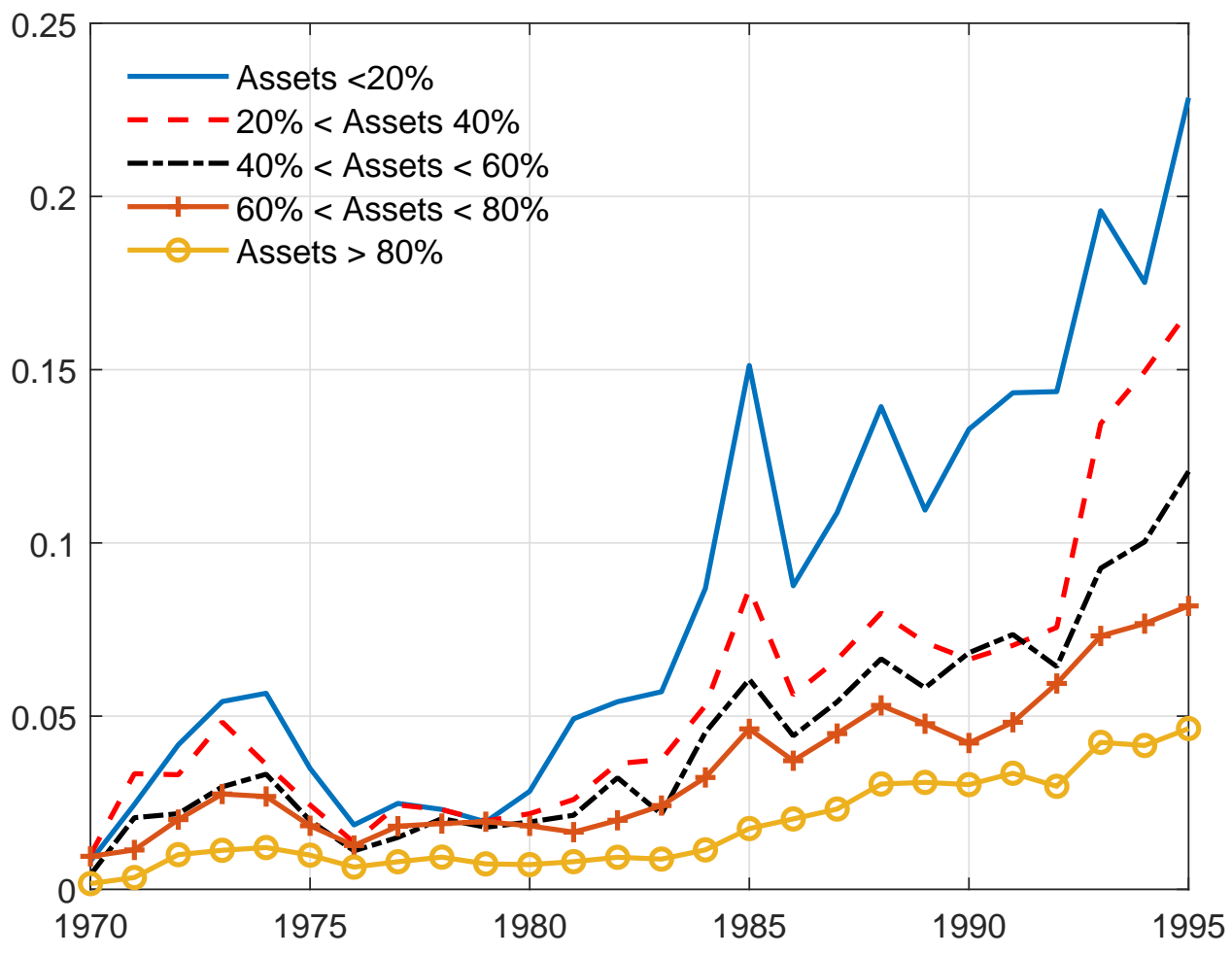


Figure IA5: Aggregate and average total share of income

This figure shows the time series of the aggregate and average capital income and labor income-to-sales ratio. The total labor income consists of the extended staff expenses (following Donangelo (2016) 37 plus NG. The capital income is OIBDP minus NG. The total labor share is the (extended XLR + NG)/sales. The top figure plots the time series of the average (extended XLR $+\mathrm{NG}) /$ sales as well as the aggregate $\sum_{i}(\mathrm{OIBDP}-\mathrm{NG})_{i} / \sum_{i}$ sales $_{i}$. The bottom figure plots the time series of the average (oibdp-NG)/sales, and the aggregate $\sum_{i}(\mathrm{OIBDP}-\mathrm{NG})_{i} / \sum_{i}$ sales $_{i}$. The sample is from 1970-1995, from the Compustat-CRSP merged database.
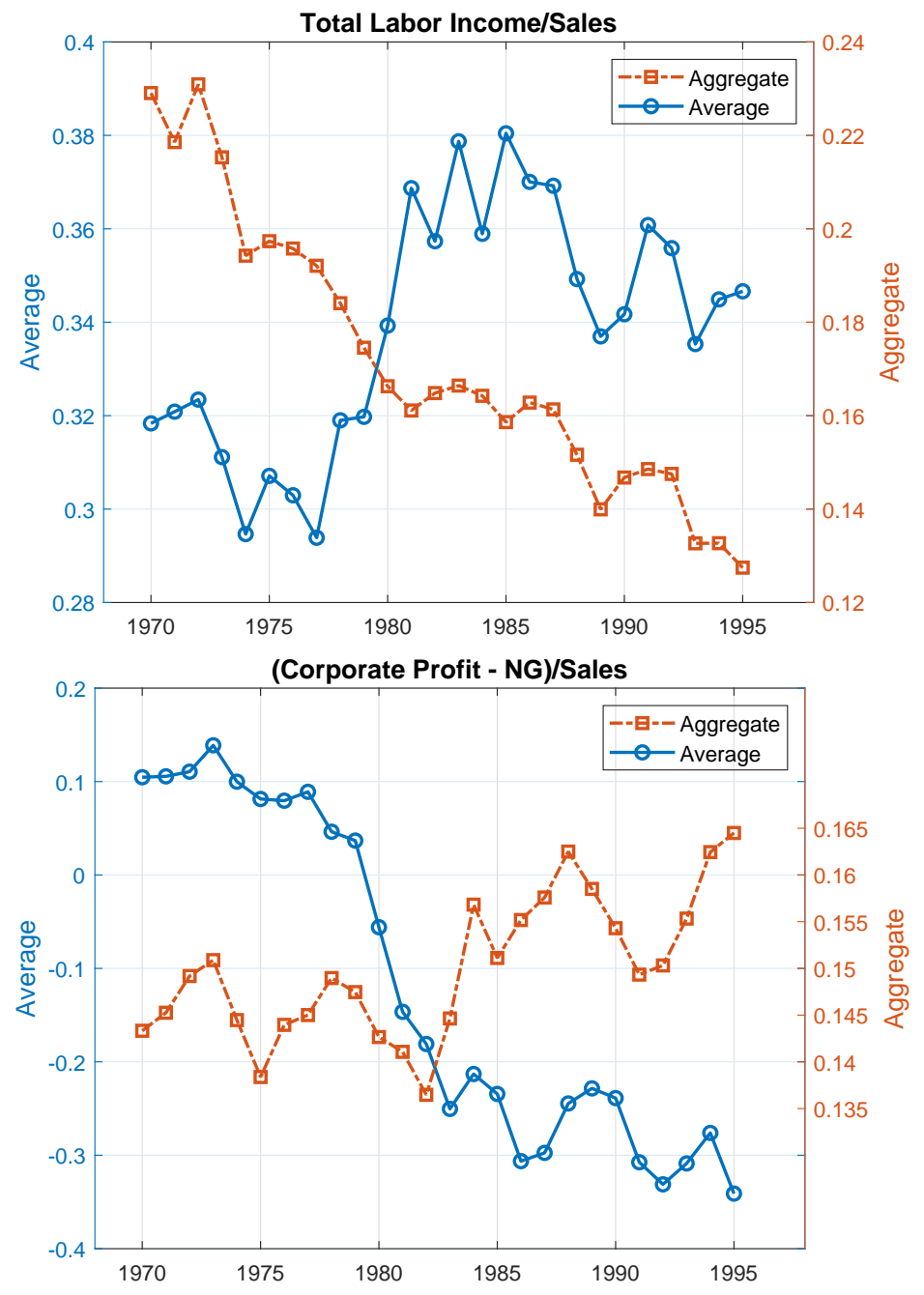


\section{Model Fit}

Figure IA6: Model Fit: Two-Step Estimation

The figure shows the model fit of the two-step estimation reported in Table 1 Panel (a) plots the model-implied time series of the relative ratio of marginal products: $\frac{s_{k}}{s_{h} \omega_{R}}$ (in red dashed line) and the actual time series from the data. Panel (b) plots the time series of the unskilled labor share from the model and the data. Compustat Fundamental Annual, RiskMetrics (IRRC), and NBER-CES Manufacturing Industry Database. The sample period is from 1980 to 2011.

(a) $\frac{s_{k}}{s_{h} \omega_{R}}$

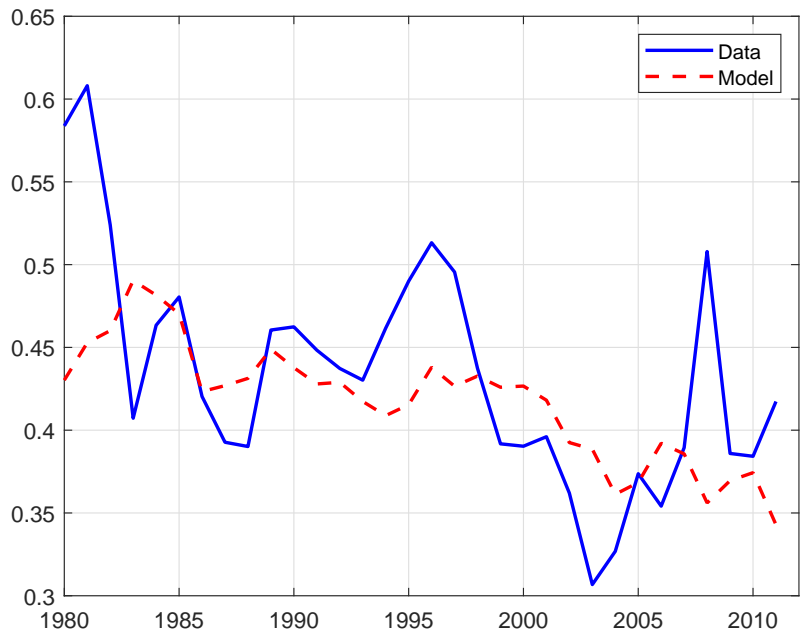

(b) $s_{n}$

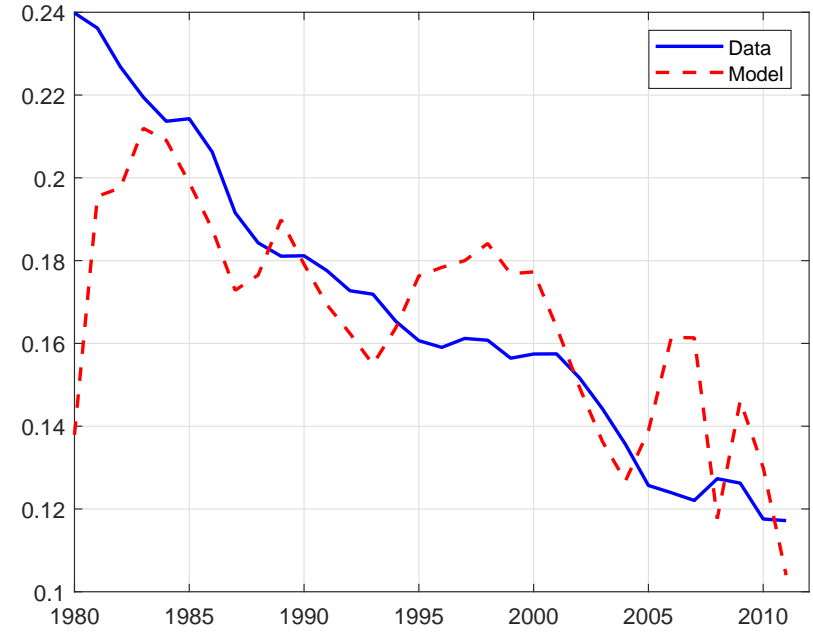

